2016-06-10

The Changing Face of Neolithic and Bronze Age Ireland: A Big Data Approach to the Settlement and Burial Records

\author{
McLaughlin, TR
}

http://hdl.handle.net/10026.1/5100

10.1007/s10963-016-9093-0

Journal of World Prehistory

Springer Verlag

All content in PEARL is protected by copyright law. Author manuscripts are made available in accordance with publisher policies. Please cite only the published version using the details provided on the item record or document. In the absence of an open licence (e.g. Creative Commons), permissions for further reuse of content should be sought from the publisher or author. 
The Changing Face of Neolithic and Bronze Age Ireland: A Big Data Approach to the Settlement and Burial Records

\section{T. Rowan McLaughlin, Nicki}

J. Whitehouse, Rick J. Schulting, Meriel McClatchie, Philip Barratt \& Amy

\section{Bogaard}

Journal of World Prehistory

ISSN 0892-7537

Volume 29

Number 2

J World Prehist (2016) 29:117-153

DOI 10.1007/s10963-016-9093-0

\section{Volume 29 Number 2 • June 2016}

\section{Journal of World Prehistory}

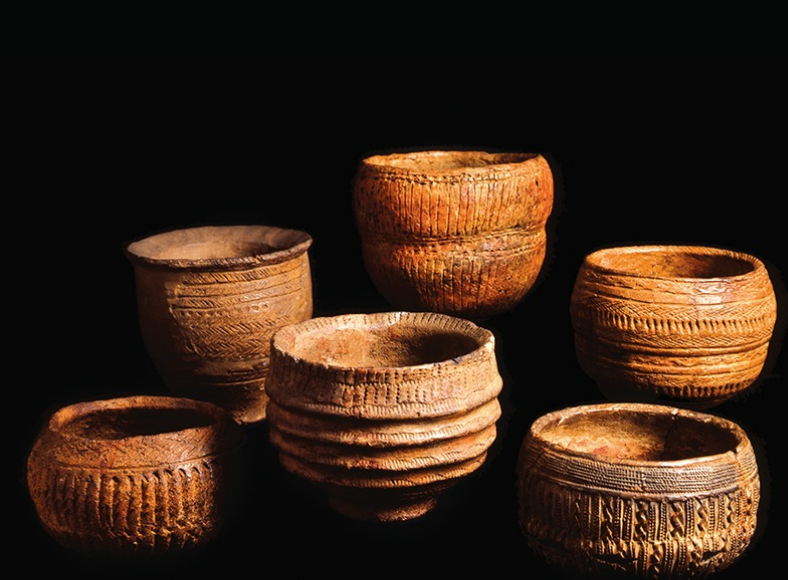

Springer

10963 • ISSN 0892-7537

29 (2) 117-216 (2016) 
Your article is published under the Creative Commons Attribution license which allows users to read, copy, distribute and make derivative works, as long as the author of the original work is cited. You may selfarchive this article on your own website, an institutional repository or funder's repository and make it publicly available immediately. 


\title{
The Changing Face of Neolithic and Bronze Age Ireland: A Big Data Approach to the Settlement and Burial Records
}

\author{
T. Rowan McLaughlin ${ }^{1}$ - Nicki J. Whitehouse ${ }^{2}$ • \\ Rick J. Schulting ${ }^{3} \cdot$ Meriel McClatchie $^{4} \cdot$ Philip Barratt $^{1,2}$. \\ Amy Bogaard ${ }^{3}$
}

Published online: 10 June 2016

(C) The Author(s) 2016. This article is published with open access at Springerlink.com

\begin{abstract}
This paper synthesizes and discusses the spatial and temporal patterns of archaeological sites in Ireland, spanning the Neolithic period and the Bronze Age transition (4300-1900 cal BC), in order to explore the timing and implications of the main changes that occurred in the archaeological record of that period. Large amounts of new data are sourced from unpublished developer-led excavations and combined with national archives, published excavations and online databases. Bayesian radiocarbon models and contextand sample-sensitive summed radiocarbon probabilities are used to examine the dataset. The study captures the scale and timing of the initial expansion of Early Neolithic settlement and the ensuing attenuation of all such activity - an apparent boom-and-bust cycle. The Late Neolithic and Chalcolithic periods are characterised by a resurgence and diversification of activity. Contextualisation and spatial analysis of radiocarbon data reveals finer-scale patterning than is usually possible with summed-probability approaches: the boom-and-bust models of prehistoric populations may, in fact, be a misinterpretation of more subtle demographic changes occurring at the same time as cultural change and attendant differences in the archaeological record.
\end{abstract}

Keywords Neolithic Ireland - Settlement - Burial - Megalithic tombs · Demographics · Radiocarbon dating

Electronic supplementary material The online version of this article (doi:10.1007/s10963-016-9093-0) contains supplementary material, which is available to authorized users.

T. Rowan McLaughlin

r.mclaughlin@qub.ac.uk

1 School of Geography, Archaeology and Palaeoecology, Queen's University Belfast, Belfast BT7 $1 \mathrm{NN}$, Northern Ireland, UK

2 School of Geography, Earth and Environmental Sciences, Plymouth University, Plymouth, UK

3 School of Archaeology, University of Oxford, Oxford, UK

4 School of Archaeology, University College Dublin, Belfield, Dublin 4, Republic of Ireland 


\section{Introduction}

In this paper we present new insights into Irish Neolithic and Early Bronze Age prehistoric settlement patterns that have been discovered during the last two decades of intensive, developer-funded fieldwork, and compare these results to the arguably more familiar monumental megalithic landscape. The overall aim is to identify points in time and space where settlement patterns were at their most dynamic, in order to examine both demographic and cultural changes and the ways in which the archaeological record challenges notions of population influxes and booms and busts. We focus on a comparison between (1) Mesolithic-Neolithic transitional sites (4300 cal BC-4000 cal BC), (2) Neolithic sites (c. $4000 \mathrm{cal} \mathrm{BC}-2500 \mathrm{cal} \mathrm{BC}$ ), and (3) sites of the Chalcolithic and opening centuries of the Early Bronze Age (c. 2500 cal BC-1900 cal BC).

Population dynamics has recently re-emerged as a subject of active debate in prehistoric studies, especially in parts of the world where large amounts of radiocarbon data are available (e.g. Peros et al. 2010; Shennan et al. 2013; Kelly et al. 2013; Crombé and Robinson 2014). The patterns of social and economic change that these studies appear to indicate-particularly oscillating patterns of activity - conflict with traditional views of the steady, slow pace of change in prehistory. Human history from the start of the Neolithic onwards-at least in Europe - has been viewed conventionally as a gradual but continual increase in the scale and complexity of social organisation (e.g. Childe 1925). By contrast, meta-analyses of large radiocarbon datasets and of archaeological sites using Bayesian chronological approaches (e.g. Whittle et al. 2011; Stevens and Fuller 2012; Feeser and Furholt 2013; Armit et al. 2013; Wicks et al. 2014; Whitehouse et al. 2014) appear to indicate a past that was highly punctuated and dynamic. This applies both to particular phenomena and to entire societies, with the latter emerging, flourishing in certain regions, and then undergoing decline, collapse or a radical restructuring as in decline-and-fall accounts of classical civilisations. These meta-analytical approaches provide a useful means of directly comparing human cultural dynamics with climatic and landscape palaeoecological data (e.g. Whitehouse et al. 2014; Wicks and Mithen 2014; Woodbridge et al. 2014) and thus have great potential for exploring human environmental impacts over the Holocene, and the creation of the cultural landscape.

Criticisms of these approaches as applied to the study of prehistory-particularly the use of cumulative probability distributions of calibrated radiocarbon dates as proxies for human populations - are centred on taphonomic considerations, and the fact that the shape of the calibration curve strongly influences the results (cf. Contreras and Meadows 2014). Archaeological materials are an imperfect record, with highly complex social factors underlying the initial deposition of the material drawn on for radiocarbon dating, whereupon millennia of taphonomic processes eventually result in the 'what' and 'where' of that which survives (Schiffer 1987). Nor are data subsequently encountered in a neutral manner by archaeologists: many biases exist as the result of research traditions and the practicalities of undertaking fieldwork. Many syntheses of radiocarbon datasets have failed to fully confront these factors, limiting the applicability of these approaches and leading to criticisms within the archaeological literature (e.g. Bamforth and Grund 2012; Contreras and Meadows 2014; Crombé and Robinson 2014; Sheridan and Pétrequin 2014). Here, we present methods whereby the imperfections and limitations of the archaeological record can be better contextualised, understood and taken into account when using meta-analytical approaches centred on radiocarbon dates.

Ireland (Fig. 1), a large European island immediately west of Britain, is divided into two territories; the northeastern quarter being Northern Ireland and part of the United 


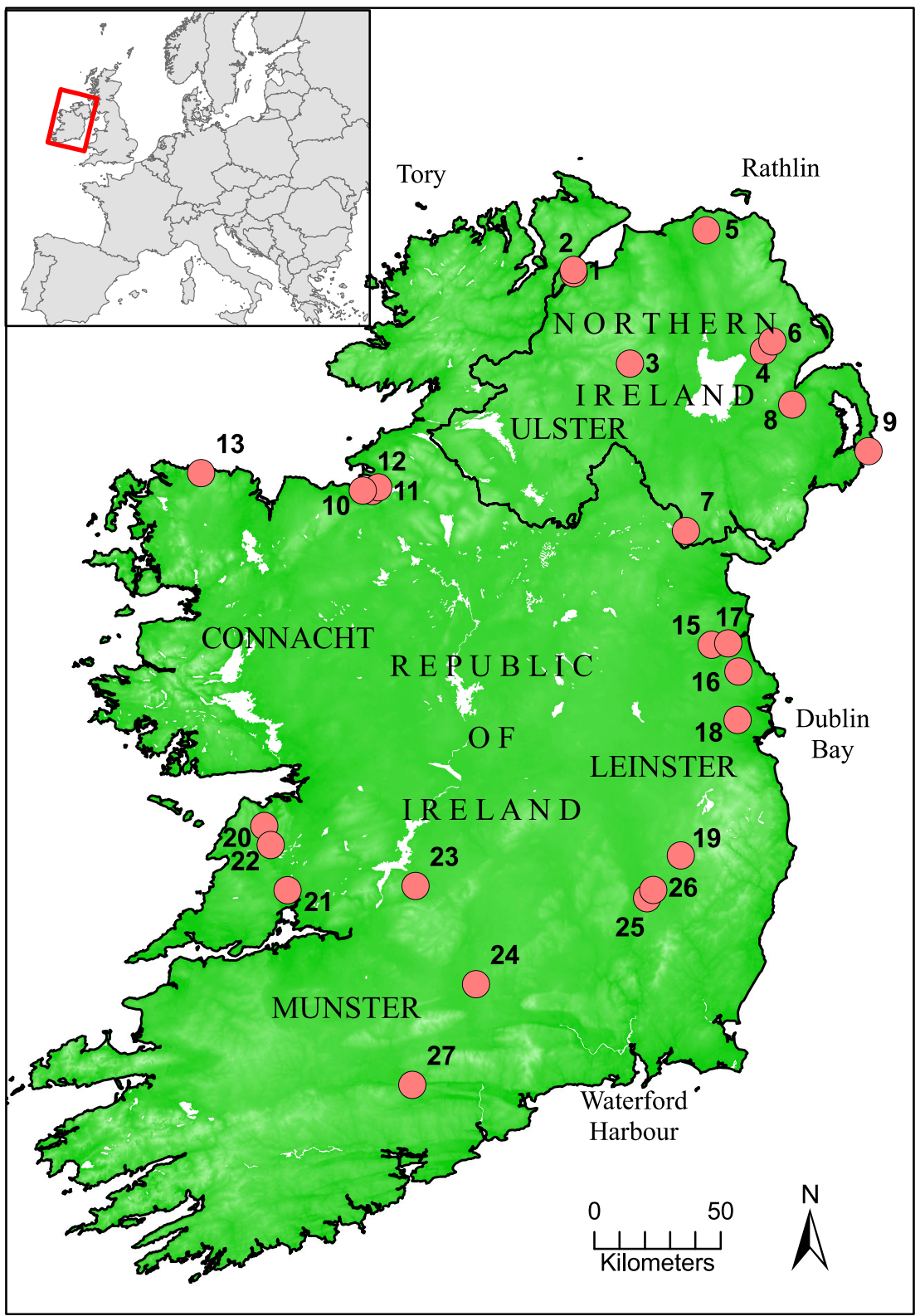

Fig. 1 Map of Ireland showing topography, major lakes and rivers, the main regions, and places and sites mentioned in the text. (1) Gransha, Co. Londonderry; (2) Thornhill, Co. Londonderry; (3) Altanagh, Co. Tyrone; (4) Donegore, Co. Antrim; (5) Liscolman, Co. Antrim; (6) Lyle's Hill, Co. Antrim; (7) Annaghmare, Co. Armagh; (8) Ballynahatty '1855', Co. Down; (9) Millin Bay, Co. Down; (10) Carrowmore complex, Co. Sligo; (11) Magheraboy, Co. Sligo; (12) Knocknareagh, Co. Sligo; (13) Belderrig, Co. Mayo; (14) Corralanna, Co. Westmeath; (15) Brú na Bóinne (Newgrange, Knowth and Dowth), Co. Meath; (16) Fourknocks, Co. Meath; (17) Rathmullan 3, Co. Meath; (18) Kilshane, Co. Dublin; (19) Baltinglass, Co. Wicklow; (20) Poulnabrone, Co. Clare; (21) Cahircalla Mor, Co. Clare; (22) Parknabinnia, Co. Clare; (23) Tullahedy, Co. Tipperary; (24) Lough Feedora, Co. Tipperary; (25) Tinryland, Co. Carlow; (26) Busherstown, Co. Carlow; (27) Fermoy 2, Co. Cork 
Kingdom, the remainder being the Republic of Ireland. A large number of developer-led excavations took place in the island-especially in the Republic-between the late 1990s and 2008, the timeframe of the most recent economic boom. A large number of prehistoric settlements of all kinds were discovered by this work (Armit et al. 2013; Ginn 2011; Whitehouse et al. 2014). In the wider context of Neolithic Europe, Ireland has a special place, being situated at the endpoint of a series of cultural, economic and demographic transformations which are among the most intensively studied in world prehistory (e.g. Barker 1985; Gronenborn 2003; Rowley-Conwy 2004, 2011; Whittle 1996; Whittle et al. 2011). Despite the newly-discovered wealth of settlement evidence, Ireland's archaeological record has not yet featured prominently in many of these accounts, except as auxiliary to British research (e.g. Thomas 2004; Stevens and Fuller 2012). This means that the connections between Ireland and its wider world have been relatively poorly explored, except perhaps within narratives concerned with technology and trade (e.g. Cooney and Mandal 1998; Cooney 2000b). Geographically, Ireland, whilst sharing many ecological similarities with Britain, also has a number of distinct biogeographic characteristics such that its records can and should be examined on their own merits (e.g. Mitchell 2005; Montgomery et al. 2014). These distinctions are primarily expressed in an impoverished flora and, particularly, fauna, presenting a rather more limited range of ecological niches for the first human colonisers in the early Holocene (only limited evidence for a Palaeolithic human presence has been found in Ireland, see Dowd and Carden 2016), and impacting on the process of neolithisation. As well as presenting no large game animals other than wild boar (red deer, roe deer and aurochs all being absent), a reduced fauna is likely to have resulted in a very different Mesolithic landscape structure due to reduced browsing pressure (Warren et al. 2014). The paucity of large game might have made Neolithic domesticated cattle, sheep, goat and pig all the more attractive to Irish huntergatherers, assuming some indigenous uptake of farming (Woodman 1985). Furthermore, the introduction of domesticated grazers into Ireland would certainly have had a range of ecological consequences, subjecting areas to grazing at levels not previously attained, perhaps ultimately leading to reduced ecosystem function and ecosystem resilience.

\section{Archaeological Context}

Traditionally, much archaeological research on the Irish Neolithic was focused on megalithic burial monuments, the distribution of surface finds, and investigations of major earthworks (e.g. Cooney and Mandal 1998; Eogan 1991; Mallory et al. 2011; O'Kelly 1982). Megalithic sites and earthworks are included in some of the analyses presented here, with the aim of comparing their chronology and geography to those of settlements. Prior to the boom in development-led excavations in Ireland (Smyth 2007, 2012), attempts to assess the extent of Neolithic settlement in the landscape were relatively limited, depending upon field-walking and analysis of the distribution of extant Neolithic earthworks and megalithic sites. Settlement, despite a lack of direct archaeological evidence, was seen as widespread, except perhaps in upland areas (Cooney 1983, 2000a, p. 223). The distribution of visible megaliths and earthworks indicates the presence of Neolithic people in certain places, and indeed could be used as a proxy for settlement, although there has been a temptation in the past to assume that the absence of evidence of megalithic tombs in certain regions equates to an absence of Neolithic people. This assumption was quickly rebutted by the first major archaeological investigations associated with infrastructure projects in Ireland (Woodman 1992). 
As infrastructural development accelerated through the 1990s and 2000s, it became apparent that Neolithic rectangular structures, usually interpreted as 'houses', were manifest throughout the island (Cooney 1999; Grogan 1996). Smyth (2006, 2007, 2010, 2014) has reviewed the evidence for these and other Neolithic buildings in considerable depth. Indeed, the ubiquity of these structures has given rise to an 'Irish model' of settlement in the Neolithic - one of permanent houses and cereal agriculture (Cooney 2000a; Bradley 2007; McClatchie et al. 2014). This model stands in contrast to Britain, most notably southern Britain, where the available evidence points towards fewer rectangular housesor settlements of any kind - and where the importance of cereals is less clear (e.g. Thomas 2004). That being said, the picture may be slowly changing there as well, with earlier Neolithic houses found at a number of locations, although it is worth noting that substantial cereal assemblages have been recovered from only some of these sites (Jones and Legge 2008; Pelling and Campbell 2013). In northern Britain, 'timber halls', comparable to but somewhat earlier and larger than Irish Neolithic houses, generally have quite substantial cereal assemblages (e.g. Fairweather and Ralston 1993; Barclay et al. 2002; Kirby 2011; Murray et al. 2009).

Rates of recovery for other types of Neolithic and Early Bronze Age settlements in Ireland have been lower than those for rectangular houses, although a large number of pit sites have been discovered (Carlin 2011b; Smyth 2012). Other sites that have been recently discovered in exceptionally large numbers are burnt mounds and single burials. Prehistoric burnt mounds in Ireland are numerous, but have only been widely excavated and dated in recent decades, as a result of developer-led projects (Ó Néill 2009). Single burials occur most often as depositions of cremated human remains in stone cists, pits or earthworks and other sites; they have been discovered throughout the island, and date to a number of distinct periods spanning virtually all of prehistory (Waddell 1970, 1990; Lanting and Brindley 1998; Brindley 1999; Collins and Coyne 2003).

\section{Methods}

Syntheses of development-led excavations have proven challenging, due to the huge volume of raw data, most of which remains unpublished. However, chronology can be a powerful tool to provide an overview of the data (Shennan and Edinborough 2006). The potential of radiocarbon chronology to revolutionize the understanding of prehistory has been anticipated for some time in Ireland (e.g. Woodman 2000). However, as the majority of radiocarbon dates from Irish sites have only become available in the last decade (Fig. 2), the potential of development-led excavations in Ireland to enhance our understanding of the past is only beginning to become apparent.

Here, we consider a database of radiocarbon dates that we have collated using published dates and date lists (e.g. Brindley 2007; Chapple 2008); unpublished site reports, the National Roads Authority's archaeological database; and direct consultation with private sector archaeologists. The Neolithic period (c. 4000-2500 cal BC) is represented by 1150 radiocarbon dates from 177 sites, with a further 739 dates recorded from 254 Chalcolithic and Early Bronze Age sites (2500-1900 cal BC). These numbers comfortably exceed the minimum 500 radiocarbon dates recommended for this type of analysis (Williams 2012). We have recorded details about material sampled for each date, its context, and various physical and archaeological parameters of each site, including geographical location and typological status, storing this information in a relational database. A compendium of published radiocarbon data and a list of sites is appended to this paper as electronic 
Irish archaeological radiocarbon dates available in $2001(n=1396)$

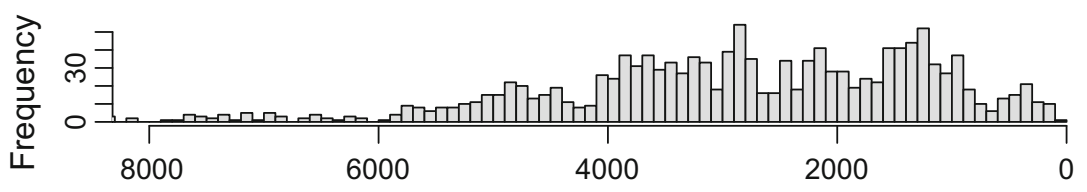

Uncalibrated radiocarbon years BP

Irish archaeological radiocarbon dates available since 2001 ( $n=4929)$

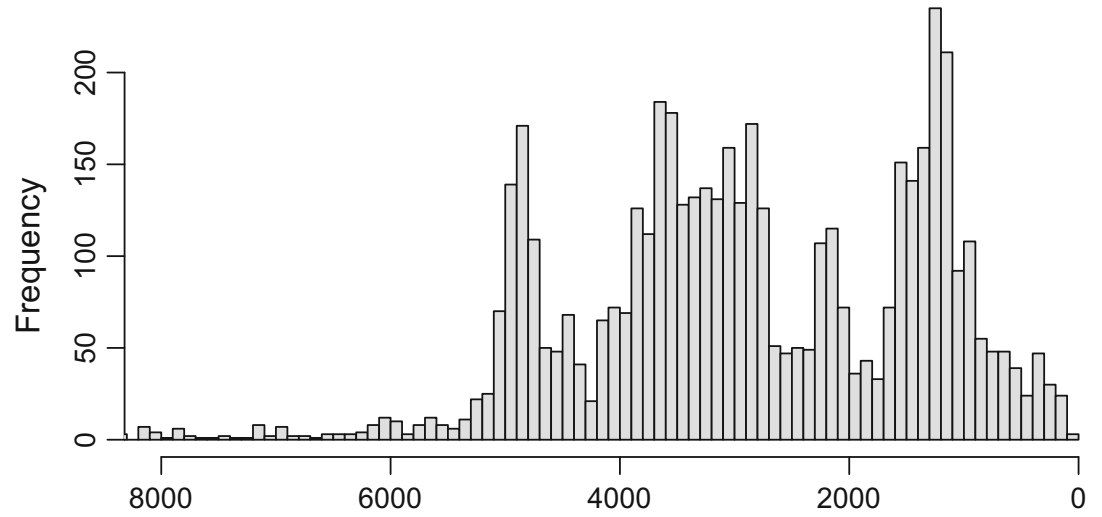

Uncalibrated radiocarbon years BP

Fig. 2 Frequencies of radiocarbon dates from Irish sites pre- and post-2001

supplementary data. For analysis, the radiocarbon database was contained in a set of data tables, structured to include a description of material dated and its archaeological context. Each record of the database also contained its archaeological context, including information about the phasing of the site, and the cultural material associated with each date. This database could be related to a list of sites that also contained geographic co-ordinates and the general category of each site, such as 'court tomb' or 'Neolithic house'. Metacategories were created to allow for all types of settlements, enclosures and burials to be dealt with either separately or together, depending on the research question. In this way, the database could be queried to provide a list of dates for a given phase at a single site, or for entire groups of different sites, or any combination thereof. The date lists were calibrated and summed using custom software written in R.

Location information was taken from the Sites and Monuments Record of the Republic of Ireland and that of Northern Ireland (hereafter collectively referred to as the SMR). We include in our database the details of excavated but as yet undated sites yielding unambiguously Neolithic material. Research on undated Chalcolithic and Early Bronze Age sites is at a less advanced stage, so these were not included in the database except for wedge tombs, cist burials and burnt mounds, details of which could be found in the SMR.

To investigate spatio-temporal patterns, the database was deployed in a Geographic Information System (GIS) and additional utilities were developed specifically for space-time analyses, using GRASS 6.4.1 for GIS operations, MySQL 5.5 for data queries and R 2.14 for radiocarbon calibration (the routine used is supplied as supplementary data) and statistical analyses. Scripts written in these environments were used to select data, plot maps and 
provide summary statistics. Radiocarbon dates were calibrated within these environments, using the Intcal13 or Marine13 calibration curves as appropriate (Reimer et al. 2013). Summed radiocarbon probability distributions were calculated separately for burial and nonburial contexts, and from charcoal and non-charcoal samples, thereby allowing for old wood samples to be excluded from the analysis if required. For the summed probability modelling, multiple dates occurring within the same phase at a given site were included in the analysis to avoid the risk of rejecting potentially interesting dates that had been erroneously attributed to a given phase - indeed the strength of summed modelling is that no assumptions about the phasing of the data are made. A comparison between the sum of all dates, and those instances where only one date per phase is considered (see supplementary data) indicates that there is little significant difference between the results. We do, however, follow an overall chronological framework for the Neolithic derived through Bayesian approaches already published elsewhere (Carlin 2011b; Cooney et al. 2011; Schulting 2014, 2015; Schulting et al. 2012; Whitehouse et al. 2014). We follow archaeological convention and present Bayesian modelled phase boundaries in italics.

This approach allows for comparisons between multiple data contexts and varying qualities. As a first step in exploring the significance of short-term fluctuations in Irish radiocarbon data, the decay model proposed by Surovell et al. (2009) was used. Surovell and his colleagues derived this model by regressing the Bryson et al. (2006) database of radiocarbon dates from volcanic eruptions against a power function in the form:

$$
\mathrm{N}_{\mathrm{t}}=\mathrm{a}(\mathrm{t}+\mathrm{b})^{-\mathrm{c}}
$$

where $\mathrm{N}_{\mathrm{t}}$ is the number of radiocarbon dates for the time period $\mathrm{t}$, and $\mathrm{a}, \mathrm{b}$ and $\mathrm{c}$ are correlation coefficients (see Surovell et al. 2009, pp. 1716-1717). The function can therefore be used to model a 'taphonomic correction' to summed probability distributions.

GIS was used to create maps of Ireland where the geographic location of each radiocarbon-dated sample could be visualized according to its context, the type of material dated and the probability that it lies within a given calibrated timeframe. Given the difficulties associated with representing detailed contextual information on such a map, sites were divided broadly into houses, enclosures, burnt mounds, burials and 'other' categories. The 'house' category includes rectangular, circular and irregular structures; the 'other' category consists mainly of 'pit-and-spread complexes'. Although individual pits are found on many sites, pit-and-spread complexes are those sites where pits and spreads of cultural material are the defining features (Smyth 2012). A set of summary statistics was produced for each category, taking the site as the unit of analysis-for example, multiple rectangular houses occurring together were counted as one site. Multiple phases occurring at one site were treated separately. A succession of maps, plotted using narrow temporal bandwidths (of the order of decades or even years) and viewed as animations, was used to visualize the changing character of the archaeological record. Static maps were also generated for longer timespans, allowing for the comparison of newly-discovered excavated sites and extant, unexcavated and undated sites whose details are known from the SMR.

For analyses of site elevation, GIS was used to store a digital elevation model of Ireland, built using Shuttle Radar Telemetry Mission (SRTM) data at 3 arcsecond resolution. A surface interpolated from this model was sampled at the point coordinates of the various sites, and the result was fed back into the database as a statistic that could be analyzed in tandem with other site attributes. Sites near errant reflections in the SRTM data were identified as outliers and excluded from elevation analysis. An average elevation statistic was calculated for most site categories, except where small numbers and topographic 
heterogeneity resulted in no clear central tendency. A random sample of 1500 points in the digital elevation model has a median elevation of $86 \mathrm{~m}$ and an interquartile range of $55 \mathrm{~m}-$ $142 \mathrm{~m}$.

\section{Results}

What follows is an overview of the evidence for archaeological sites in Ireland, 4300-1900 cal BC. For convenience, the Neolithic period is divided into transitional, Early, Early/Middle, Middle and Late periods, following conventions already established (McClatchie et al. 2014; Whitehouse et al. 2014). We also explore the presentation of spatial-temporal trends in the data without recourse to categorisation by time period, via animated mapping and presentation of overall trends using summary statistics and summed radiocarbon probabilities.

\section{Final Mesolithic Ireland}

Later Mesolithic in Ireland, which can be distinguished from earlier phases on the basis of the stone tools that characterize it, began around $6700 \mathrm{cal} \mathrm{BC}$ and ended with the arrival of farming (Woodman 2015, pp. 232-233). Settlement evidence from the period is rare, and from 4200 cal BC rarer still (Woodman 2015, p. 330). Late Mesolithic artefacts have, however, been found in contexts securely dated to approximately $4000 \mathrm{cal} \mathrm{BC}$ at Belderrig, Co. Mayo (Warren 2008); Corralanna, Co. Westmeath (Warren et al. 2009); and Tinryland, Co. Carlow (O'Connell 2009). Some time after this point, possibly as early as $3720 \mathrm{cal} \mathrm{BC}$, the first hints of a Neolithic presence emerge, although the evidence is by no means unequivocal and there are no known settlement sites.

\section{Early Neolithic I, Pre-3720/3680 cal BC}

Recent assessment of the radiocarbon record using Bayesian methods has dated the appearance in Ireland of cereals and rectangular houses-both clear markers of the presence of Neolithic people-to no earlier than 3720-3680 cal BC (Cooney et al. 2011; Whitehouse et al. 2014). The start of the Neolithic in Ireland has traditionally been placed at c. $4000 \mathrm{cal} \mathrm{BC}$, but this relied on a small number of potentially aberrant charcoal dates, and on the earlier part of $95 \%$ confidence intervals on radiocarbon dates on human and animal bone. For reasons discussed by Whitehouse et al. (2014) and outlined later in this paper, early dates on wood charcoal from settlement sites unfortunately make no great contribution to our knowledge of the earliest Neolithic in Ireland. At Ferriter's Cove (Woodman et al. 1999), and more tentatively at Kilgreany cave (Woodman et al. 1997), cattle bones dating to $4300 \mathrm{cal} \mathrm{BC}$ and $4000 \mathrm{cal} \mathrm{BC}$ hint at a Mesolithic contact with Neolithic Britain or continental Europe (there is no wild bovine native to Ireland), or alternatively suggest that Neolithic cattle farming had already become established in a way that is otherwise invisible archaeologically. On the other hand, evidence for cereal agriculture during this period (aside from inconclusive palynological data: Behre 2007; Whitehouse et al. 2014) is lacking altogether, though this should be seen in the light of the fact that the overwhelming majority of cereal samples are derived from rectangular structures, which date to a later time (McClatchie et al. 2014). 
The best evidence for a Neolithic presence in Ireland before $3720 \mathrm{cal} \mathrm{BC}$ is found in the burial record. Individuals buried at Altanagh, Co. Tyrone (Murphy et al. 2010) and Poulnabrone, Co. Clare (Schulting 2014) lived around 3800 cal BC. It is possible that these people were among Ireland's first farmers, whose culture was just beginning to gather momentum on the island, and whose settlements are yet to be discovered by fieldworkers. Certainly, the scale of deposition of archaeological material of all kinds before $3720 \mathrm{cal}$ $\mathrm{BC}$ is limited, whilst the profusion of sites after this date indicates a radical transformation of human society and its associated cultural landscape.

\section{Early Neolithic II, 3720/3680-3640/3620 cal BC}

Sites dating to the Early Neolithic II (ENII) period, encompassing the Neolithic 'house horizon' of 3720/3680-3640/3620 cal BC, are shown in Fig. 3. Extant portal and court tombs are included here, in addition to excavated and dated sites, although it should be noted that neither type of monument has been as thoroughly excavated or dated as the settlements now are. The chronology of portal tombs is poorly known, although the limited available data support an early appearance, namely pre-3720 cal BC (Kytmannow 2008; Schulting 2014). Construction of court tombs began during the interval 3700-3570 cal BC, and their initial phase of use for burial probably continued slightly longer than did that of rectangular houses (Schulting et al. 2012). Deposition at two passage tombs sites-the Carrowmore complex, Co. Sligo, and Baltinglass, Co. Wicklow-also began at this time (Bergh and Hensey 2013; Schulting et al. 2016), although many Irish passage tombs are of the later (post-3400 cal BC), more 'developed' kind typified by Newgrange and Knowth, and undated examples are not shown in Fig. 3.

The archaeological evidence for Early Neolithic settlement in Ireland is relatively wellresolved by Atlantic European prehistoric standards. The rectangular structures shown in Fig. 3 are all irrefutably Early Neolithic in date (McSparron 2008; Cooney et al. 2011; Whitehouse et al. 2014), as are the causewayed enclosures at Donegore, Co. Antrim, Lyle's Hill, Co. Antrim and Magheraboy, Co. Sligo, the Kilshane enclosure, Co. Dublin, and the enclosed settlement at Tullahedy, Co. Tipperary (Cooney et al. 2011; Schulting 2011; Mallory et al. 2011). Also shown in Fig. 3 are individual burials (including finds of human bone in caves) that date to the period of interest.

Considerable uncertainty surrounds the dating of many Early Neolithic pit-and-spread complexes, as the majority of these sites are dated only by radiocarbon determinations on charcoal samples_-problematic due to potential old wood effects. At least one pit complex of Early Neolithic date, Gransha, Co. Londonderry, may in fact be an example of a rectangular Neolithic house site where depositional and taphonomic factors have rendered the structural features less recognisable than usual (Schulting and Reimer 2008; Whitehouse et al. 2014).

Taphonomic and research biases are inherent in any distribution map, as discussed later in this paper. Notwithstanding these, the Early Neolithic archaeological record in Ireland is highly resolved chronologically from around $3700 \mathrm{cal}$ BC and over the ensuing century. Of special interest are those areas where many different site types have been found in close proximity, particularly Lough Foyle and Dundalk Bay, which offer some of the most detailed views of Early Neolithic life available anywhere in Atlantic Europe. Furthermore, significant regional patterns can be identified. For example, in the southeast of the island, both settlement sites and portal tombs are found along an inland corridor between Waterford Harbour and Dublin Bay (see Fig. 1). Notably, very few of these sites are found near the coast, except at the endpoints of this distribution. Over the northern half of the 


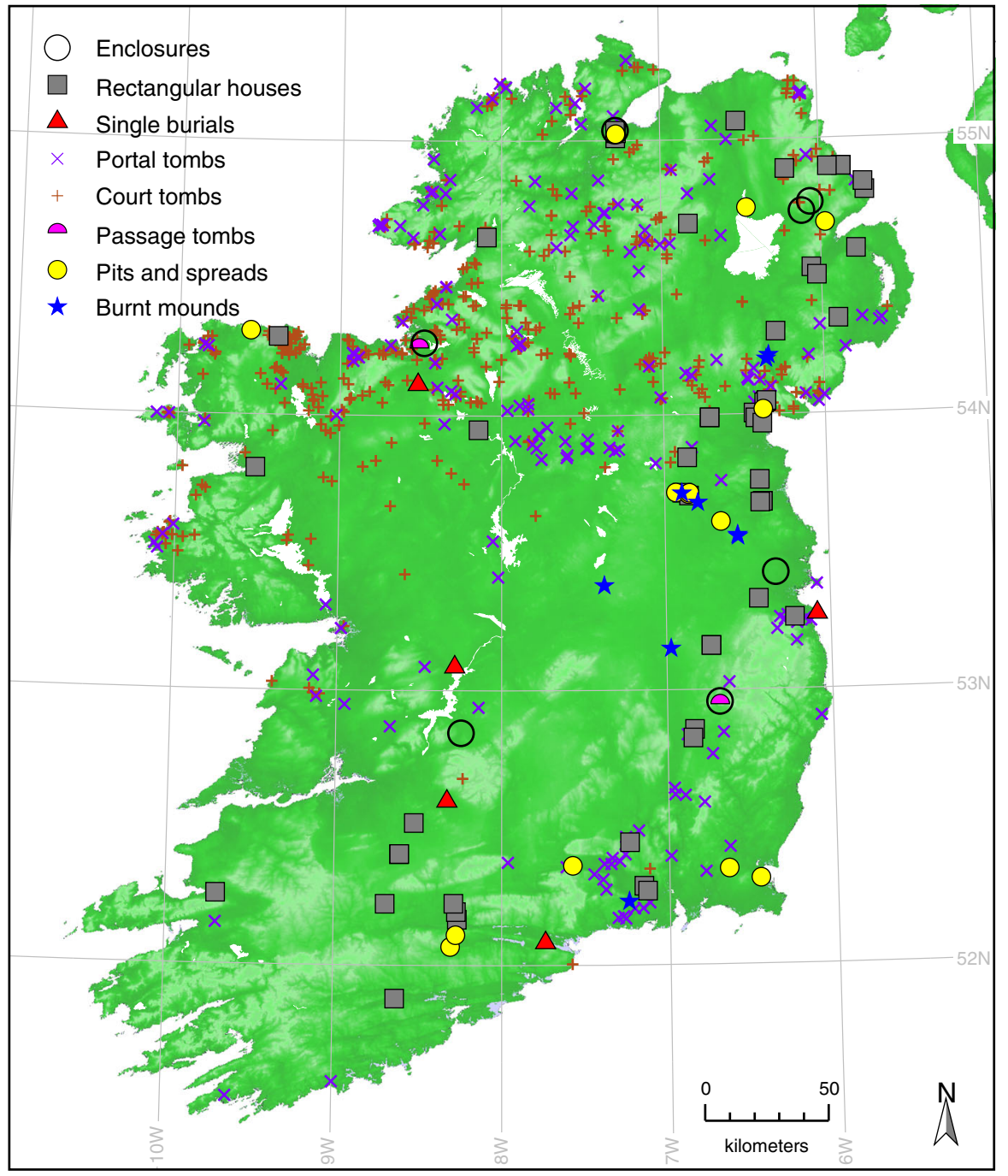

Fig. 3 Map of Ireland showing Early Neolithic sites

island, settlements are spatially associated with both portal and court tombs, and the settlements have a more marked coastal distribution, whereas in southeast Ireland, there are several settlement sites but very few tombs.

\section{Middle Neolithic I, 3640/3620-3400 cal BC}

A transitional period occurred in the Irish Neolithic from just before 3600-3400 cal BC, termed Middle Neolithic I by McClatchie et al. (2014) and Whitehouse et al. (2014). In these centuries, rectangular houses fell into disuse, and the settlement archaeology is dominated by complexes of pits and spreads of midden material (Fig. 4). At such sites, evidence for formal structures is scarce: structural evidence is still present in the form of 


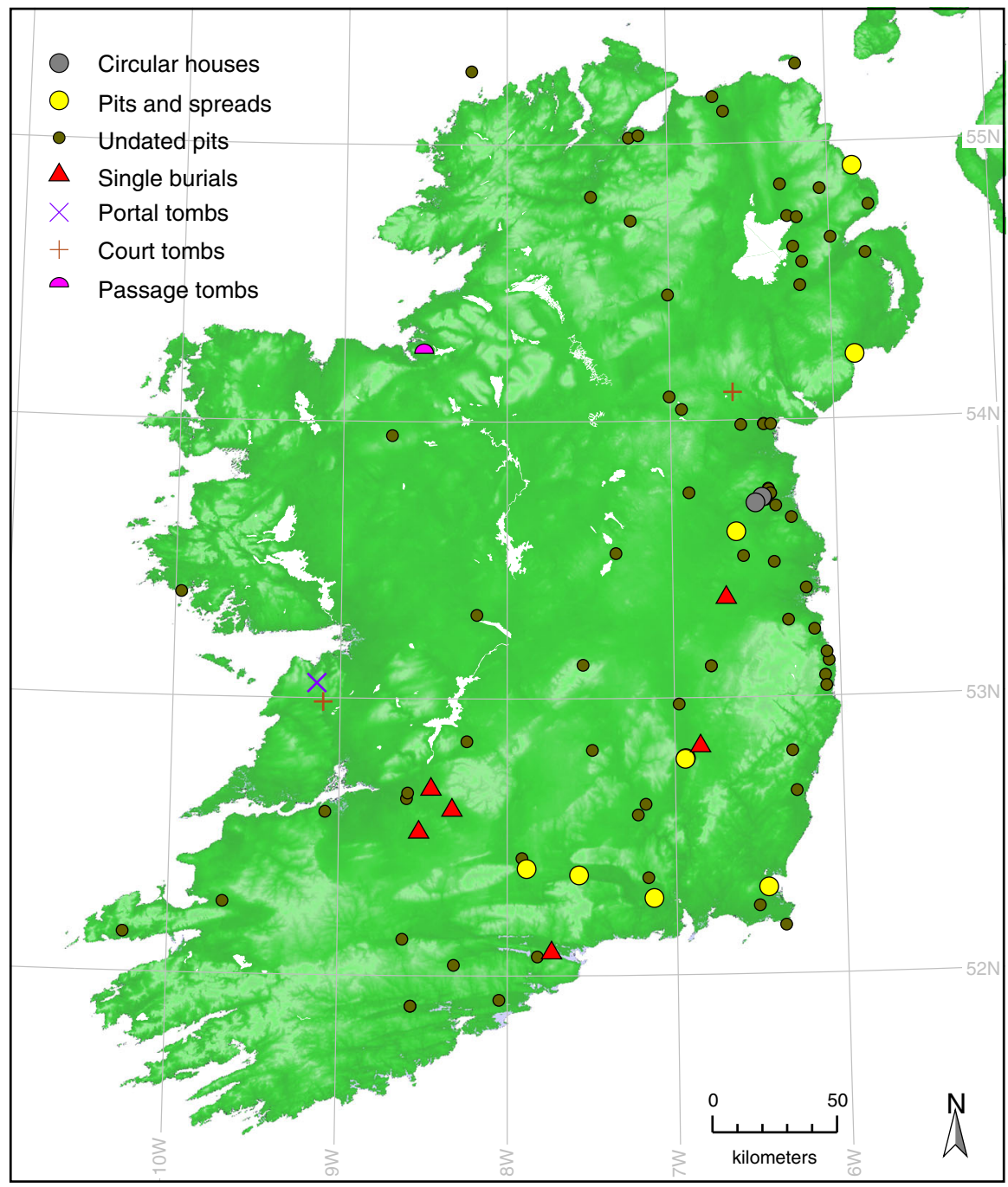

Fig. 4 Map of Ireland showing sites of the Early-Middle Neolithic transition. Note that many of the pit complexes plotted here are undated

post-holes and stake-holes, but only in a small number of cases do these resolve into the plans of buildings whose general layout (typically circular) can be seen on the ground (Smyth 2010). These sites are shown in Fig. 4. Bayesian modelling of the dates from pit complexes indicates that they end by $3520 / 3460$ cal BC (Whitehouse et al. 2014). The overall pattern of settlement during this period is therefore one of declining activity compared to the preceding ENII phase.

The nature of the funerary landscape for this period is complex. Some portal tombs, court tombs and early passage tombs were still being used for burial, although it is possible 
that these megalithic sites were no longer being constructed. For example, there is evidence for phases of intensive passage tomb use at Carrowmore, Co. Sligo (Bergh and Hensey 2013), and the deposition of human remains continued at the court tombs of Annaghmare, Co. Armagh and Parknabinnia, Co. Clare (Schulting et al. 2012) and at the portal tomb at Poulnabrone, Co. Clare (Lynch 2014; Schulting 2014). The continuing engagement with Early Neolithic funerary monuments in a changing landscape is implied, even if construction declined or ceased. Due to the uncertainties involved, only megalithic structures known to be in use during this period are shown in Fig. 4. Also shown are the single burials known from this period, including one that was found enclosed within an undated but presumably earlier Neolithic house at Busherstown, Co. Carlow (Ó Néill 2009).

Figure 4 also shows the distribution of excavated pit complexes where diagnostic Early to Middle Neolithic material has been identified but, at the time of writing, has not been radiocarbon dated. These are more widespread than Early Neolithic settlements- their distribution includes the midlands, coastal Leinster and the northern offshore islands of Rathlin and Tory (see also Fig. 1). Following a recent review by Cooney et al. (2011), and an extensive radiocarbon dating programme by Whitehouse et al. (2014), it seems that most well-dated pit complexes fall within this Early-Middle Neolithic transition period, albeit during the earlier part of the phase, that is, between 3600 and 3500 cal BC, providing an indication of the absolute chronology of similar, undated sites.

\section{Middle Neolithic II, 3400-3000 cal BC}

During the Middle Neolithic II period, there was a flourishing megalithic tradition, manifested in passage tombs-a diverse and complex category of burial site-and other monuments such as the Linkardstown-type burials and the atypical Co. Down megaliths: Millin Bay and Ballynahatty '1855'. These sites are shown in Fig. 5, along with the circular house at Knocknareagh, which may date to the same period on the basis of dated charcoal (Burenhult 1984). Several well-known passage tombs were in use during the latter part of this period, including Knowth, used as a cemetery during the period 3160-3045 cal $B C$ (Schulting et al. 2016); The Mound of the Hostages, where the main phase of burial began 3285-3075 cal BC (Bayliss and O'Sullivan 2013); and Newgrange, where dates from the turf mound indicate a construction falling within the range 3305-3020 cal BC (Schulting 2015).

This period continues the trend of decreasing visibility of settlement in the Middle Neolithic I phase from c. 3500 cal BC onwards. There are a small number of pit complexes (shown on Fig. 5) that have been tentatively dated to this period: Liscolman, Co. Antrim (Gilmore 2008); Lough Feedora, Co. Tipperary (Doody 2008); and Fermoy 2, Co. Cork (O'Connell 2003). It is worth discussing the archaeology of these three sites in greater detail, as they are the only known candidate settlements from this period. Aside from the radiocarbon evidence, no Middle Neolithic material, such as diagnostic pot sherds or lithics, was found at Lough Feedora or Fermoy 2. The feature that was dated at Liscolman - a posthole - contained a single hollow scraper, typical of the Middle Neolithic in Ireland, but this does not make a strong case for definitive Middle Neolithic settlement there because it was found in a mixed context containing both Late Neolithic Grooved Ware and Early Bronze Age food vessel pottery (Dunne 2008). Only one charcoal determination from each of the three sites falls within this date range. Furthermore, given that Late Neolithic and/or Early Bronze Age phases have also been identified at Liscolman 


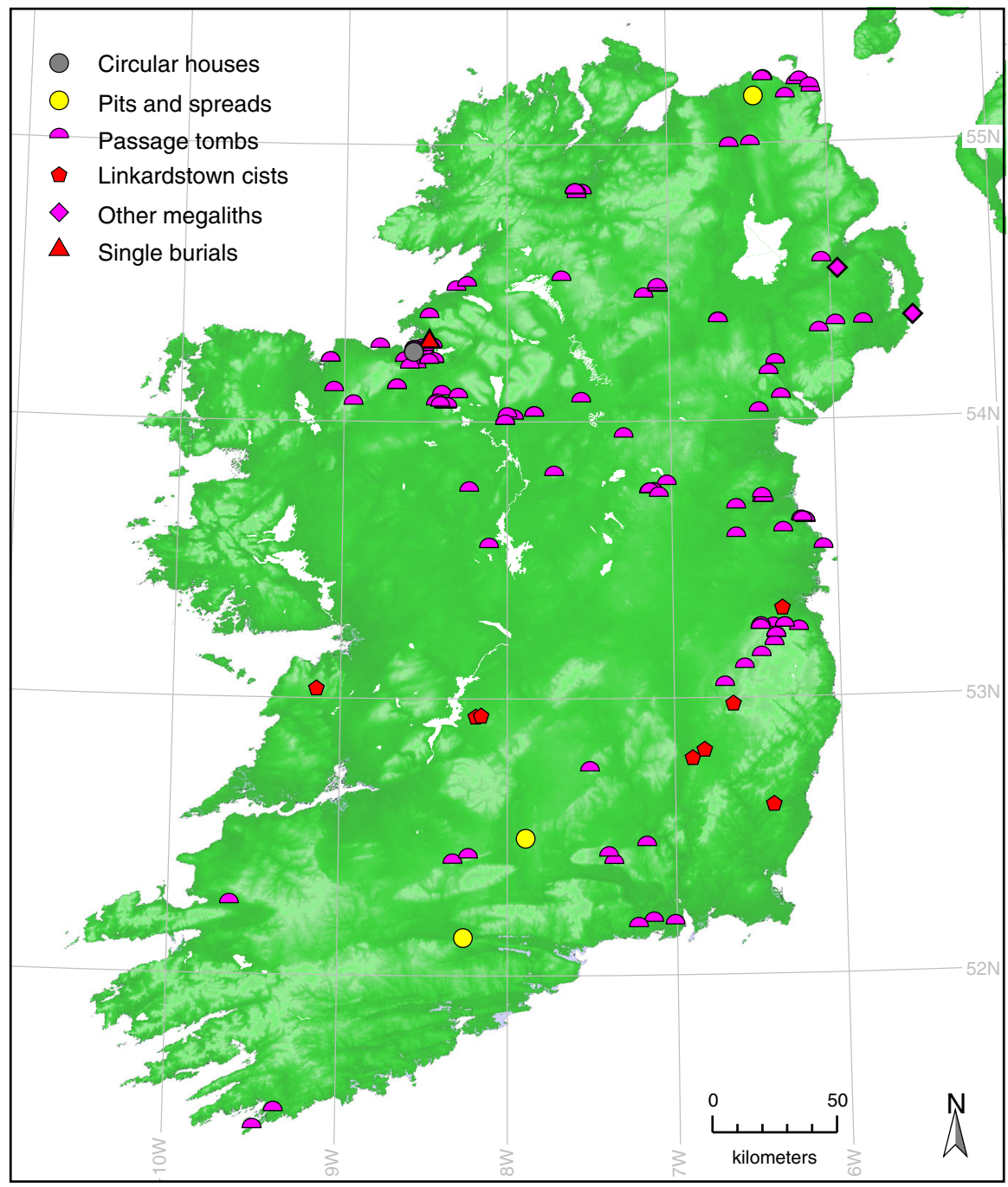

Fig. 5 Map of Ireland showing Middle Neolithic sites

and Fermoy 2, there is a high probability that the old wood effect has caused erroneous attribution of later phases of occupation to the Middle Neolithic period.

The overall pattern, therefore, is of very low archaeological visibility of settlement sites of all kinds in the Middle Neolithic in Ireland, despite an exhaustive search of all relevant archives. This situation strongly contrasts with the visibility, diversity and importance of megalithic structures, which are widespread over much of the island, though concentrated in a number of localities, the best-known being Brú na Bóinne (Boyne Valley), Co. Meath. It seems clear that whatever settlement structures were being used during this period, their potential for generating archaeological signals was very low. Perhaps this was due to a preference for earth rather than timber as the main building material, and the lack of any 
requirement to dig features deeply enough into the subsoil to create persistent archaeological features in the first place.

\section{Late Neolithic Ireland, 3000-2500 cal BC}

From around $3000 \mathrm{cal} \mathrm{BC}$, signals of settlement slowly begin to proliferate in the archaeological record, following the hiatus in settlement evidence observed during the Middle Neolithic. This broadly coincides with the end of the main phase of burial in passage tombs, at or before $2900 \mathrm{cal} \mathrm{BC}$ (Brindley et al. 2005; Bayliss and O'Sullivan 2013; Schulting 2015; Schulting et al. 2016).

A range of different site-types was in use during this time (Fig. 6). Many are associated with Grooved Ware pottery, which was introduced to Ireland from northern Britain at the start of the Late Neolithic period (Sheridan 2004). Late Neolithic settlements again took the form of complexes of pits, postholes and spreads; these have been found during development-led excavations with a similar frequency to pit complexes of the EarlyMiddle Neolithic transition. Indeed, a theme of diversity runs through the archaeological record of the Late Neolithic. Burial traditions of the period were varied, involving the deposition of cremated human remains in pits, individual burials, burials in cairns in upland regions and re-use of pre-existing megalithic structures, but in general the evidence for all these activities is sparse.

In the Late Neolithic, timber again became an important building material, although not with the ubiquity previously observed in the Early Neolithic. Various 'timber circles' are known to date to this period-exhibiting a wide variety of scales and formats, and allowing for both ritual and domestic interpretations of the archaeological remains (Smyth 2010). There is a concentration of timber circles in the Boyne Valley, reinforcing the continued importance of this special Neolithic landscape (Fig. 6).

The distribution of Late Neolithic pit complexes and timber circles in the landscape also coincides with henges, as shown in Fig. 6. Over twenty of these monuments are known from Ireland but none has been well dated, so their chronological relationship with the settlement sites remains a research question of key importance for the period.

\section{The Chalcolithic-Early Bronze Age Transition, 2500-1900 cal BC}

The Middle and Late Neolithic saw a millennium of relatively low site density, in strong contrast to the large number of sites dating to the opening centuries of the metal-using ages. During this period, from c. $2500 \mathrm{cal} \mathrm{BC}$, the archaeological record consists of pit complexes, wedge tombs, individual burials (frequently in cists), and burnt moundscommonplace field monuments often called fulachtai fiadh. With the exception of wedge tombs, these sites are widespread across the island, and are frequently found in midland regions devoid of Neolithic sites (Fig. 7).

Burnt mounds comprise concentrations of burnt stones and charcoal whose original function was heating troughs of water. Because they were built from stone, rather than earth or timber, they are highly visible; hundreds of fulachtai are known in every Irish county. Development-led excavations have revealed that many more burnt mounds exist as ploughed-out spreads of burnt stone and charcoal, often at the base of drumlins and in natural hollows near streams or marshland. Morphologically similar spreads of burnt material can date to a number of distinct Neolithic and Bronze Age periods (Hawkes 2014; Ó Néill 2009). Some 7000 burnt mounds are described in the SMR, and over 1000 new examples have been discovered and excavated during development-led projects in recent 


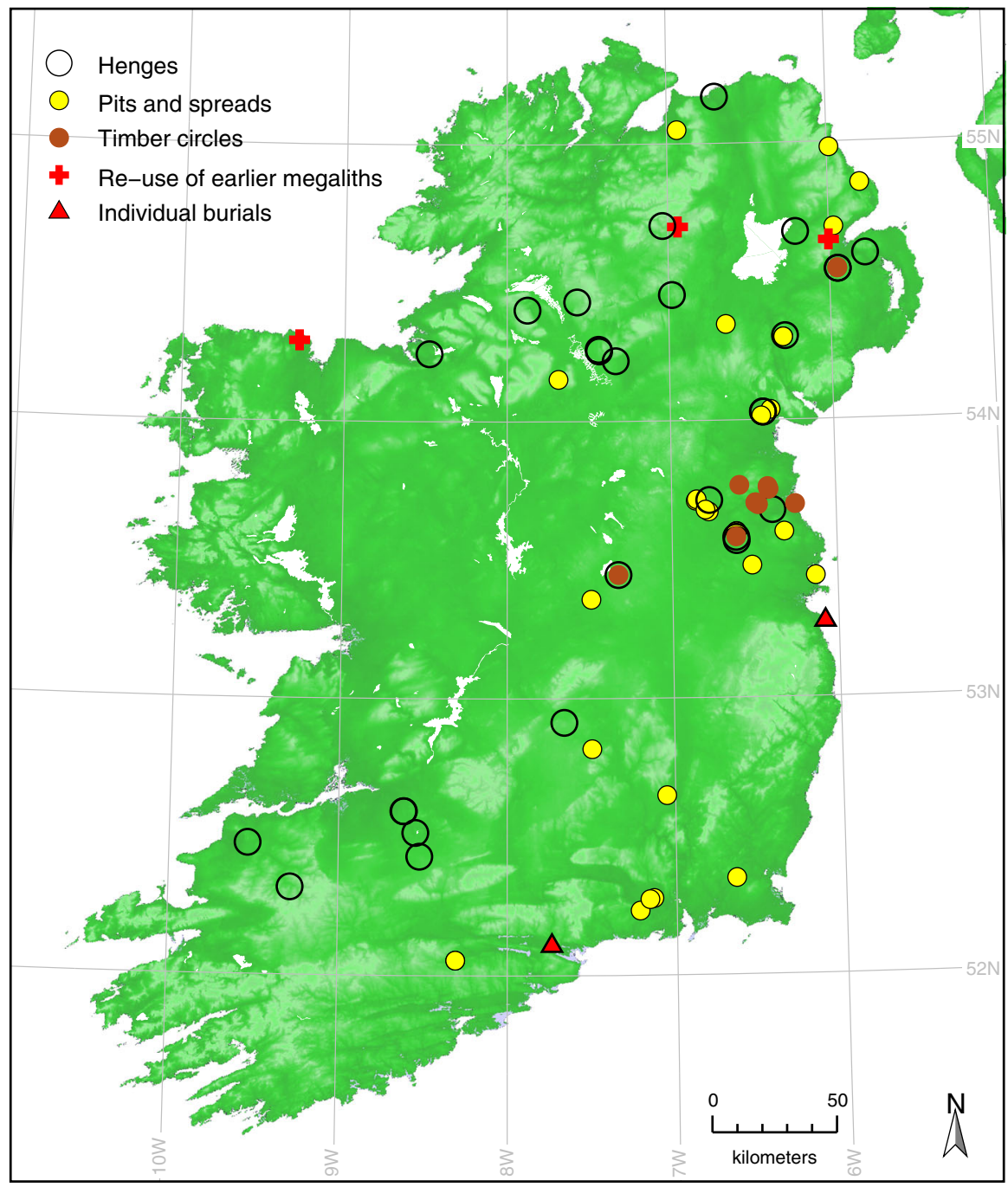

Fig. 6 Map of Ireland showing Late Neolithic sites

decades. A major phase of construction and use of these sites occurred from 2500 to 1900 cal BC: approximately half of the 236 dated sites in our database fall in this timeframe, with most of the other examples dating to later in the Bronze Age.

Some of the earliest Bronze Age pit complex sites are associated with Beaker pottery (Carlin 2011a, b). Pits containing Beaker pots are also quite frequently found at earlier megalithic sites, and are also coincident at later settlements. The chronology of Beaker settlements is represented in the database by 26 radiocarbon dates from 19 sites, falling between 2500 and $2300 \mathrm{cal}$ BC. In a detailed analysis, Carlin (2011b) has proposed a timeframe of 2460 cal BC-2200 or 2100 cal BC for Beaker settlements, occurring as part of a wider phase of use of this pottery style in various contexts in Ireland, beginning 2604/ $2473 \mathrm{cal} \mathrm{BC}$ and ending 2196/2022 cal BC. Other Early Bronze Age pit complexes are 


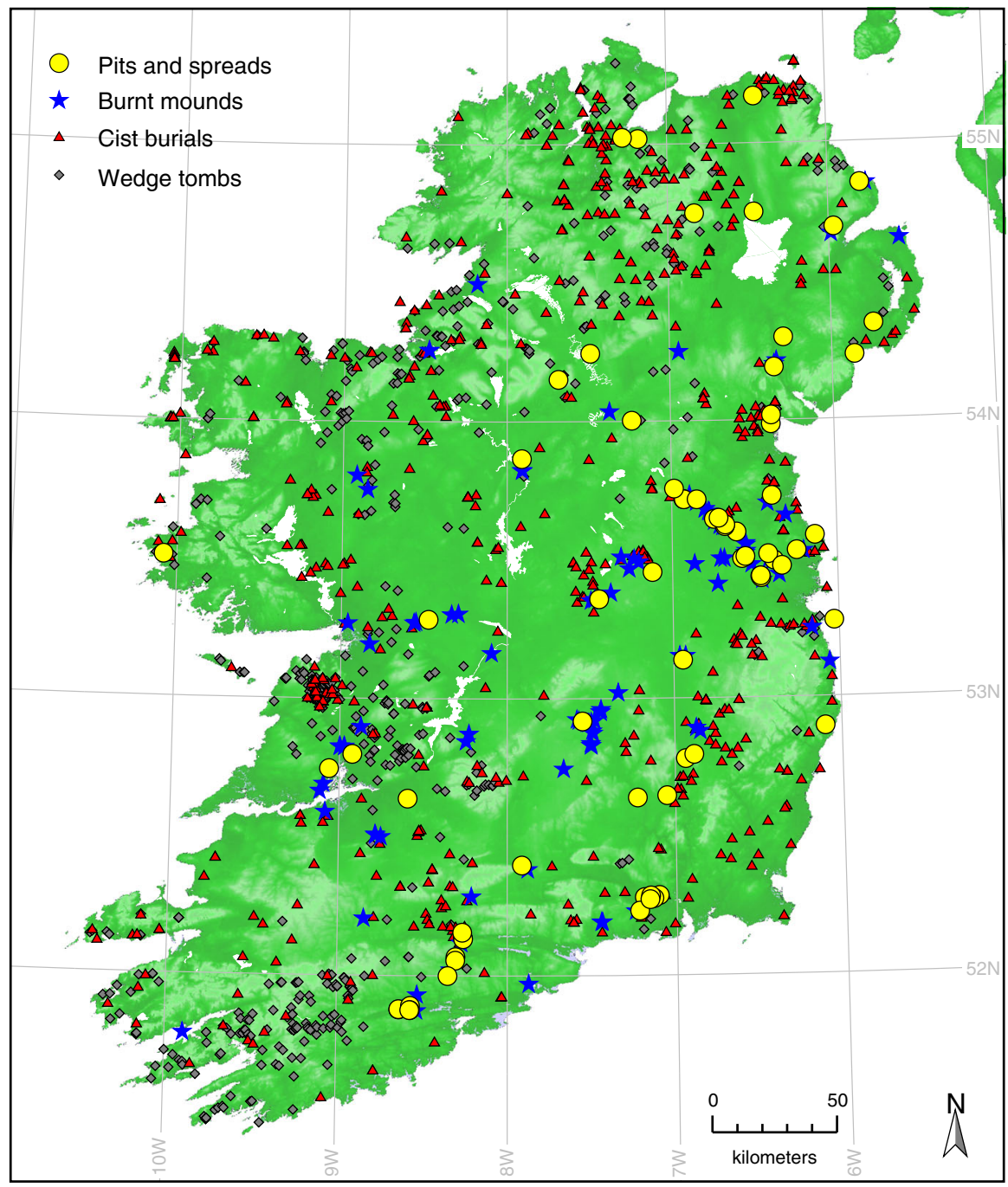

Fig. 7 Map of Ireland showing Early Bronze Age sites

either aceramic or associated with insular pottery styles such as Food Vessels. More work is needed to ascertain if there are any strong chronological patterns in the patterns of deposition at these sites.

Wedge tombs are traditionally associated with the first metal-using people in Ireland: a brief Chalcolithic phase (O'Brien 2012). Research using Bayesian methods suggests they were in use from 2300 to $2000 \mathrm{cal} \mathrm{BC}$ (Schulting et al. 2008). Although megalithic structures are usually equated with the Neolithic, wedge tombs are the most common category of prehistoric mortuary monument on the island (de Valera and Ó Nualláin 1982; see also Table 1). The period from 2500 to $2000 \mathrm{cal} \mathrm{BC}$ also sees the re-use of a significant number of megalithic structures (Brindley et al. 2005; Carlin 2011a; Schulting et al. 2012; Bayliss and O'Sullivan 2013). Most of the well-dated excavated megalithic sites display 


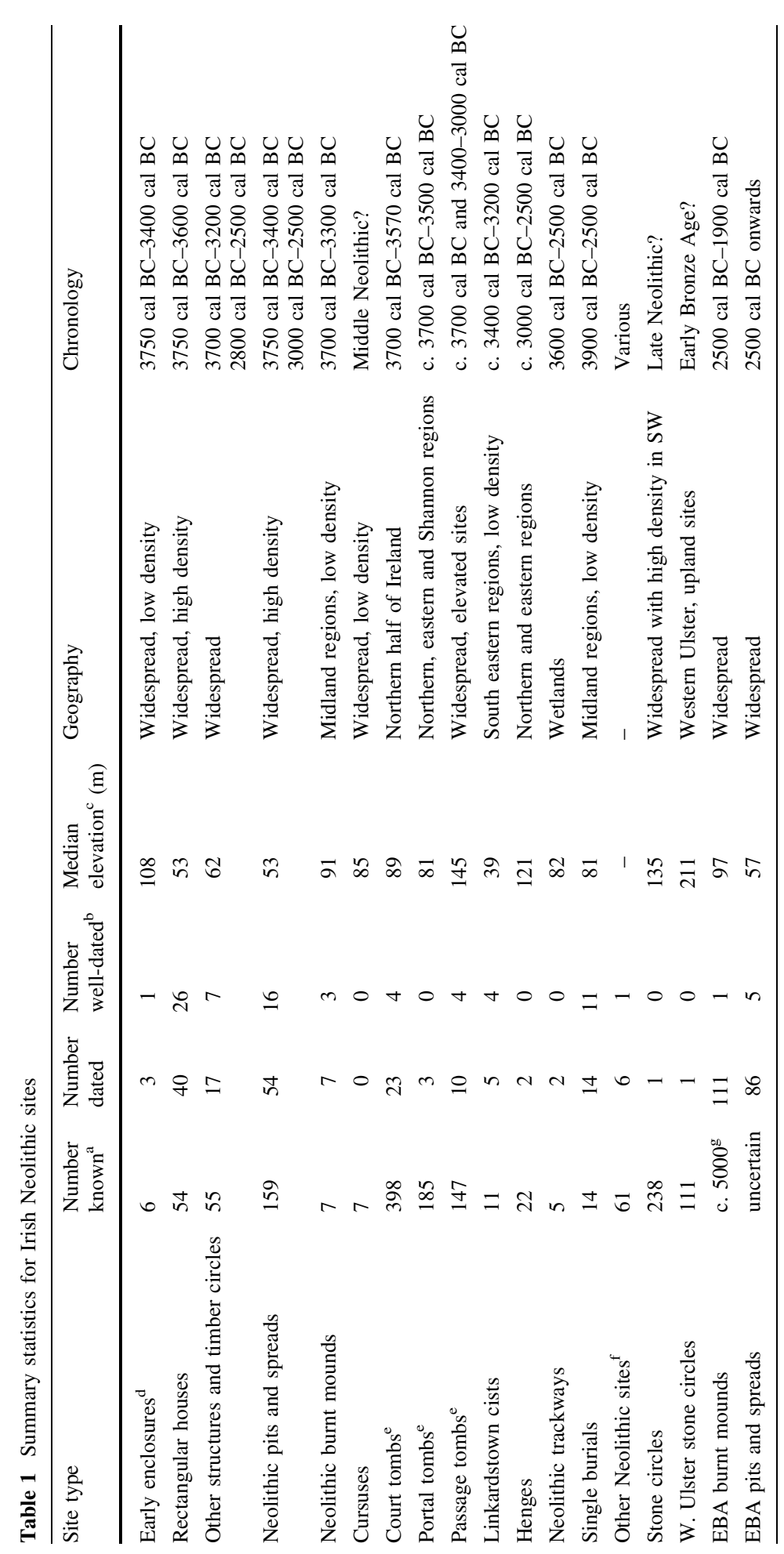




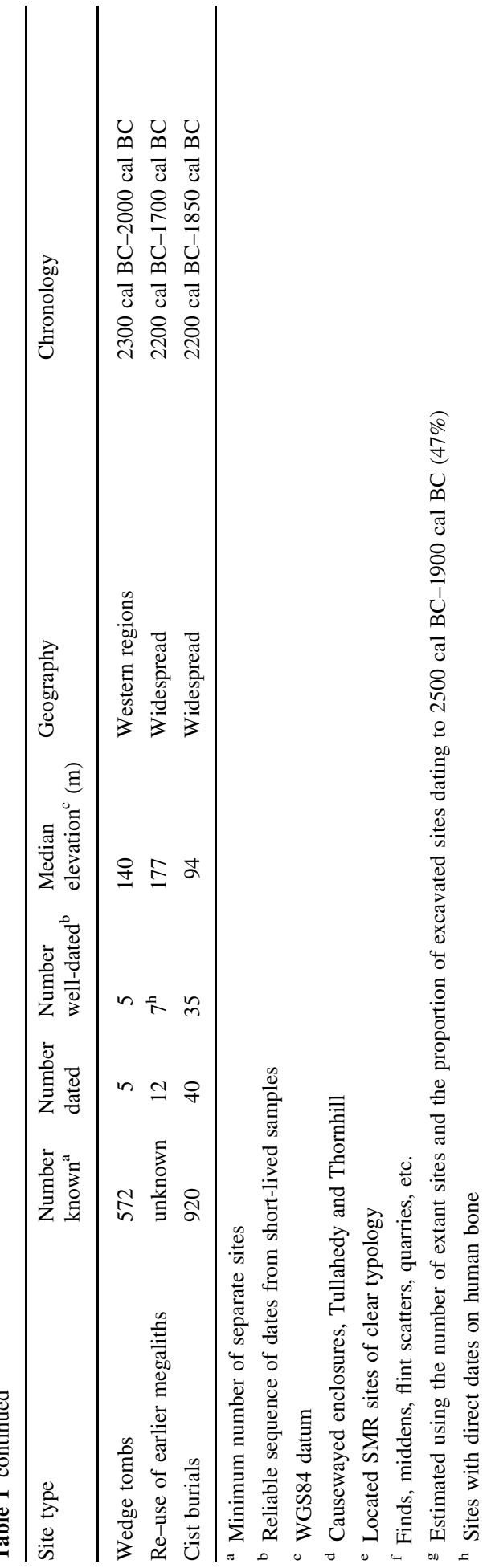


signals of Chalcolithic or Early Bronze Age re-use; it is therefore tempting to speculate that the practice was very widespread.

Cist burials are a well-studied type of site associated with Food Vessel pottery, and extensive dating programmes have established that they were constructed over the period 2200-1850 cal BC (Brindley 2007; Waddell 1990). It is, however, noteworthy that during development-led excavations, cists are found far less frequently than burnt mounds, thus highlighting a traditional bias in archaeological research, which has concentrated upon burials and related artefacts.

\section{Animated Radiocarbon Map}

Figure 8 provides a visualisation of the distribution of archaeological radiocarbon dates from Ireland. An animated version of the map can be accessed via the electronic supplementary materials. For every frame of the animation, each radiocarbon date is plotted using a point whose shape is dictated by the type of site from which the sample originated. The size of the point is directly proportional to the probability that the sample dates to a particular year, and the material dated determines the colour of the point. The threshold
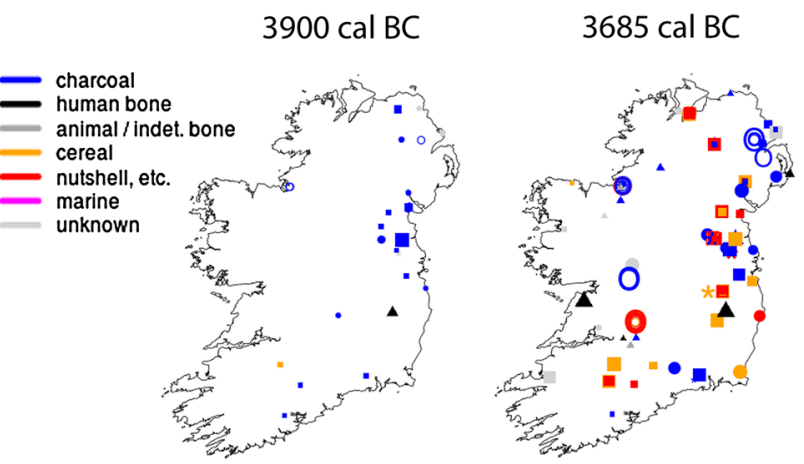

3485 cal BC

- house

O enclosure

- burial

3255 cal BC

2915 cal BC

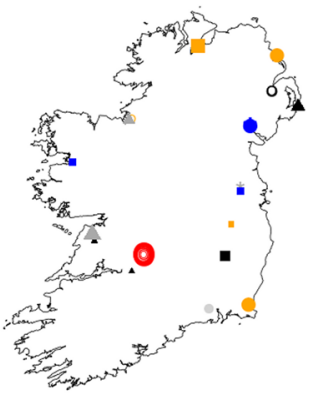

* burnt mound
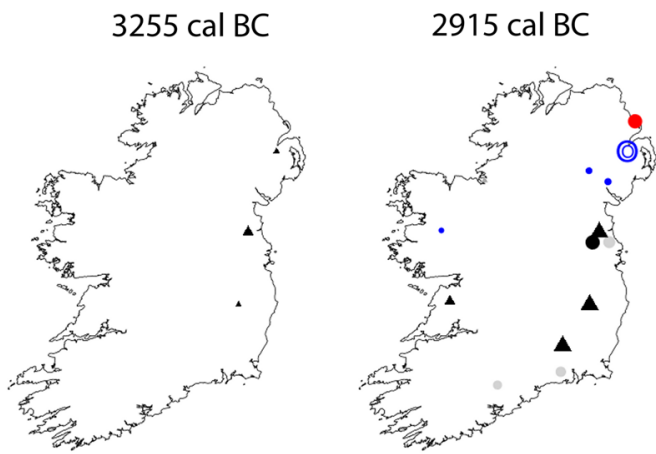

2100 cal BC

- other

Fig. 8 Example frames from an animated map of Irish sites 4500 cal BC-1900 cal BC. Static frames display determinations whose probabilities intersect the date shown - the shape of each point indicates the sample's context and its colour indicates the material dated. An animated series of maps, 4500 cal BC$1900 \mathrm{cal}$ BC, is supplied as supplementary data (Color figure online) 
timeframe for each point is approximately equivalent to the span of the calibrated date's 99\% confidence interval, and each point increases in size over the span of the $68 \%$ confidence interval with a maximum occurring at the modal year (or years) of the calibration.

The animated map begins at $4500 \mathrm{cal} \mathrm{BC}$, illustrating the sparse distribution of Late Mesolithic sites (though this represents an increase from the preceding centuries). From the outset, charcoal samples from Neolithic contexts are also visible, highlighting the magnitude of the old wood problem. Because a sample's point size reflects the probability that the sample dates to that particular year, the shape of the calibration curve affects the point size and the dots on the map can be seen to oscillate accordingly. The old wood effect becomes increasingly problematic around 4000 cal BC-which until recently was the orthodox date for the start of the Neolithic period. From approximately $3800 \mathrm{cal} \mathrm{BC}$, dates from cereals start to become visible; these are the left-hand tails of the probability distributions of the calibrated dates.

In the decades following 3750 cal BC, activity increases markedly, coinciding with the Neolithic 'house horizon' (Cooney et al. 2011; McSparron 2008; Whitehouse et al. 2014). Increasing activity can also be noted among many charcoal samples at this time, illustrating that the old wood effect does not necessarily apply to every sample. After a brief but widespread lull at around $3600 \mathrm{cal} \mathrm{BC}$, which is the end of period of use for rectangular houses, activity at pit complexes remains widespread until approximately $3400 \mathrm{cal} \mathrm{BC}$. At this point, cereal dates decrease in frequency, disappearing entirely by $3350 \mathrm{cal} \mathrm{BC}$. As discussed by McClatchie et al. (2014) and Whitehouse et al. (2014), interpretation of this is not straightforward, as there is a strong sampling (and therefore dating) bias towards cereals from rectangular structures.

From 3400 to 2900 cal BC, passage tombs and Linkardstown-type burials dominate the archaeological record. These too fluctuate in frequency, with very few sites dating to around $3300 \mathrm{cal} \mathrm{BC}$ for example, even if charcoal samples are included. This is despite the presence of a centuries-long plateau in the calibration curve beginning around $3350 \mathrm{cal} \mathrm{BC}$ (Brindley 1999; Schulting et al. 2016).

The Late Neolithic period, to $2500 \mathrm{cal}$ BC, is characterized by a resurgence and diversification of activity, with dates from a number of burials and Grooved Ware settlements becoming visible in the animations. As 2500 cal BC approaches, a number of charcoal samples from burnt mounds appear, although many of these are from Bronze Age contexts, and plotted early due to the combination of the old wood effect and another plateau in the calibration curve.

The density of charcoal dates from burnt mounds increases, reaching a maximum at around $2300 \mathrm{cal} \mathrm{BC}$ and persisting until the end of the study period at $1900 \mathrm{cal} \mathrm{BC}$. Dates from pit complexes are also shown in the animation, and although less frequent than burnt mounds, these too are quite widespread. At around $2200 \mathrm{cal} \mathrm{BC}$, dates from cist burials become manifest. Initially, such burials are found more densely in southern regions of the island, then their distribution appears to move northwards before finally becoming more even by $2100 \mathrm{cal} \mathrm{BC}$. This suggests that this burial tradition was introduced to the south of the island, and became more widespread following a period of northward expansion or diffusion. This is a new, unexpected result emerging from visualizing the data in this manner. The ability of the animated map to resolve these fine-grained prehistoric cultural and/or demographic changes is tantalising; assessing the significance of these observations will make for interesting further research. 


\section{Summary Statistics for Neolithic and Early Bronze Age Sites}

Overall spatial and temporal trends for the main site categories are listed in Table 1. Here, data are provided for sites not plotted in the maps: stone circles, whose chronologies are obscure, and infrequent site types such as cursuses and trackways. The relationship between stone circles and other sites is difficult to ascertain. In Britain, stone circles are understood to be broadly contemporary with henges (Burl 2000) and thus Late Neolithic in date, although the limited chronological evidence from Scotland suggests such sites were active for considerable periods of time, including well into the Bronze Age (e.g. Bradley 2006). Indeed, in Ireland, a concentration of stone circles in western Ulster is thought to date to the Bronze Age, based on environmental evidence (Pilcher 1969). Although there is a likelihood that other Irish stone circle sites date to the Late Neolithic, the chronology of these sites is intrinsically difficult to ascertain with any precision. None of the small number of extant cursuses have been excavated or dated. At present, it seems reasonable to presume they date to the Middle Neolithic, based on excavated British examples and their associations with the passage tomb cemeteries at Brú na Bóinne and Fourknocks (Barclay and Bayliss 1999). Trackways are important as they provide archaeological signals of prehistoric people in wetland areas; they are primarily a feature of the Bronze Age and later, with the few known Neolithic examples lacking any chronological focus (Brindley and Lanting 1998; O'Sullivan et al. 2014).

The median elevations for the different site categories listed in Table 1 suggest that there may be interesting patterns in the data worthy of further exploration. There is a striking similarity between the elevations of rectangular Neolithic houses and Neolithic and Early Bronze Age pit complexes, both presumably denoting settlement. Kolmogorov-Smirnov tests indicate no significant differences between the distribution of the elevations of undated and dated Neolithic pit complexes $(\mathrm{D}=.15, p=.49)$, Neolithic houses and pit complexes $(\mathrm{D}=.15, p=.29)$ and Early Bronze Age pit complexes and Neolithic settlements $(\mathrm{D}=.13, p=.34)$. Burials in both the Neolithic and Early Bronze Age were placed on a greater range of elevations, but, not surprisingly, their average elevation tends to be higher than that of settlements.

\section{Summary Chronology and Archaeological Activity Levels}

A sum of the probability distributions of radiocarbon dates for Neolithic and Early Bronze Age Ireland is shown in Fig. 9, which also illustrates the differences between the distributions of dates from charcoal samples and other entities such as charred hazelnut shells, seeds, cereals and bone. In addition, dates from funerary contexts are plotted separately from those of settlements and enclosures, thus forming a visual comparison between the overall patterns of data from these differing site types.

The most obvious feature in this plot is the peak that occurs in the Early Neolithic period, from c. $3750 \mathrm{cal}$ BC. This has two main causes. Firstly, the shape of the IntCal13 calibration curve leads to higher probabilities being computed in this region, as the distribution of uncalibrated dates does not show such a pronounced peak in the Early Neolithic (around $5000{ }^{14} \mathrm{C}$ yrs BP, see Fig. 2). Additionally, as discussed below, there is considerable bias towards Early Neolithic archaeology, partly due to the high visibility of these sites in the archaeological record, and partly due to strong research interest in this pivotal epoch. In Fig. 9, the rectangular house horizon of 3720-3680 cal BC is indicated by the distribution of dates from short-lived samples. The distribution of charcoal dates can be seen to peak earlier, at around $3900 \mathrm{cal} \mathrm{BC}$, illustrating the remarkable abundance of old-wood charcoal in samples from Early Neolithic rectangular structures. 


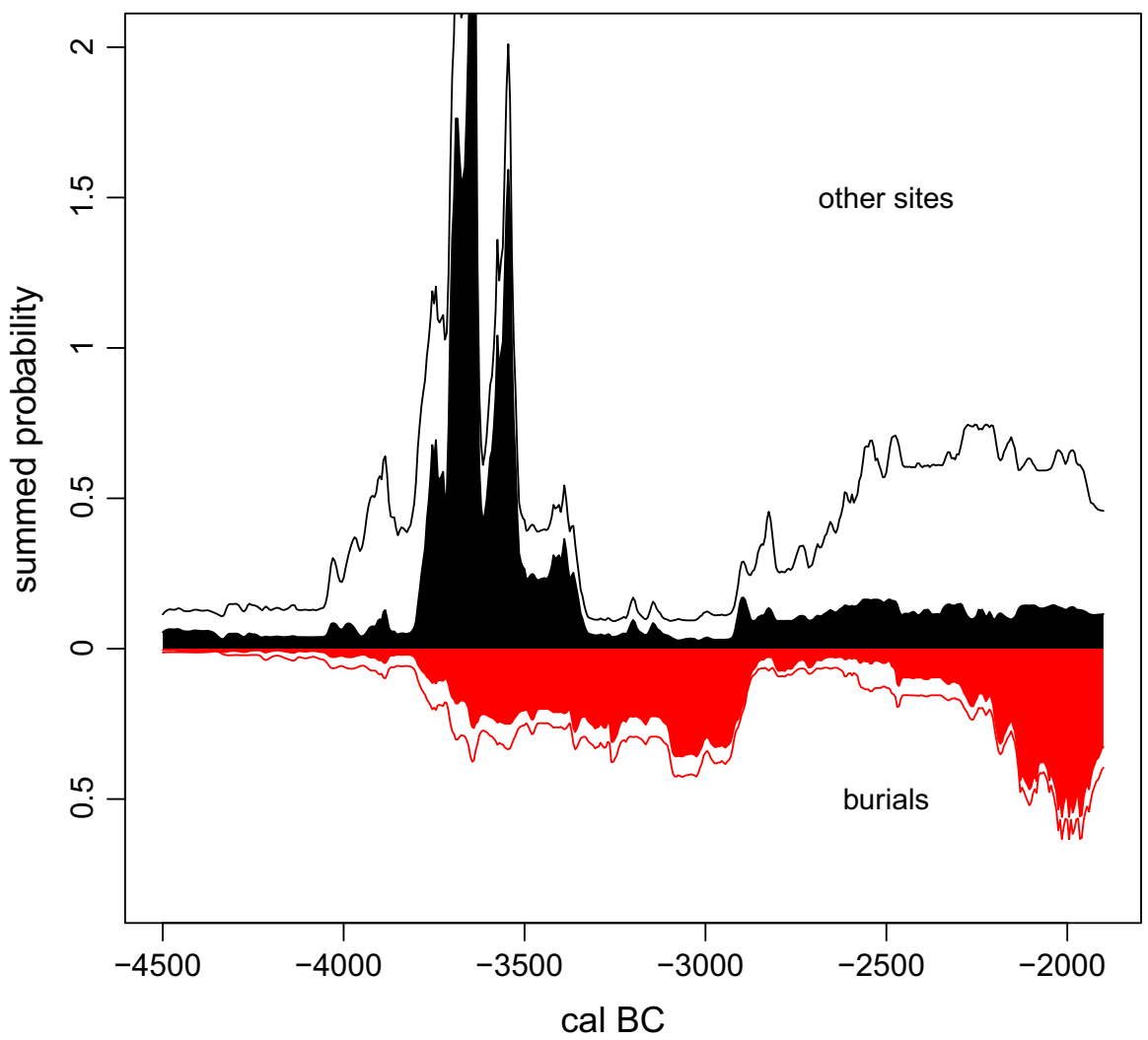

Fig. 9 Summed probability distributions for burials and other site types. The filled areas indicate the probability distribution for determinations on bone and short-lived samples, the lines indicate the addition of dates on charcoal to the overall probability distribution

The plot also shows the brief but pronounced lull in activity that occurred towards the end of the rectangular house phase at $3600 \mathrm{cal}$ BC (also noted in the animated map, Fig. 8). Then, following a period of intense activity during the Early-Middle Neolithic transition, activity from non-burial contexts is greatly attenuated, underlining the paucity of evidence for settlement sites in this period. There is a high level of burial activity until just after $3000 \mathrm{cal} \mathrm{BC}$, when there is a shift back towards deposition in non-burial contexts, which persists throughout the Late Neolithic. The Early Bronze Age is characterized by increasing activity levels from burial contexts and sustained high levels of activity from non-burial contexts. However, much of the activity from Late Neolithic and Early Bronze Age contexts is indicated by charcoal determinations.

It is noteworthy that these significant patterns in radiocarbon data would be invisible if the data from all contexts were condensed together, as is usual in summed probability studies (Williams 2012). These patterns show how useful the summed calibrated probability approach can be if the analysis remains sensitive to sample material and contextual information and prompts some further analysis of pit complexes, discussed below. 


\section{Discussion}

\section{Bias in Archaeological Datasets}

Any map of the distribution of archaeological sites is inevitably strongly influenced by both research biases and taphonomic factors. In Ireland, considerable bias results from the fact that most excavated Neolithic sites are close to contemporary urban centres, or along major roads and pipeline routes. Conversely, extant sites are more likely to exist in regions remote from modern-day development and intensive agriculture. Taphonomic considerations arise from the nature of the sites themselves. There is an obvious distinction between sites constructed of stone and those of earth or timber: the latter rapidly degrade and disappear whereas the former remain visible unless buried by peat, hillwash or subsequent human activity. Hence there are numerous sites consisting of stone, such as megalithic tombs and burnt mounds, still visible in the landscape. The great value of development-led excavations in Ireland is the discovery of many previously unknown timber and earth-built sites (Cooney 1999; Smyth 2007; Woodman 2000), albeit with a bias towards certain locations (natural route-ways); however, they are less valuable as regards research agendas, as the sites are chosen by the pressures of development rather than existing understanding of the archaeological landscape. Extrapolating from the relatively small proportion of the island's surface that has been subject to archaeological investigation, it is likely that a very large number of rectangular houses and pit complex settlements once existed.

Taking these considerations into account, there are correlations between the geographic distributions of megalithic tombs and Early Neolithic settlements, particularly in northern and northeastern coastal areas and along inland river valleys in southeastern Ireland (Fig. 4). Northwestern Ireland, where megalithic concentrations are at their highest, has seen less excavation but Early Neolithic sites feature prominently in the work conducted there, including the important and potentially very early causewayed enclosure at Magheraboy (Danaher 2007; Cooney et al. 2011). The exception to this pattern occurs in southwestern Ireland, which was extensively settled in the Early Neolithic but is largely devoid of megalithic sites. Therefore, despite the various biases, there are regional differences in the distribution of settlement sites and megalithic tombs in Ireland, and this observation parallels those made elsewhere concerning aspects of the design and siting of the megalithic sites themselves, and the material culture of the period (Cooney 2000b).

Choices made during post-excavation work also influence the patterning of data. Pits and spreads are simple features, and as such they offer less scope for interpretation than houses and burials. Consequently, given finite resources, Irish archaeologists have been somewhat reluctant to subject them to specialist analyses and radiocarbon dating, in contrast to some other types of prehistoric site. The relative numbers of dated and undated sites in Table 1 illustrate this pattern. At the time of writing, $71 \%$ of rectangular house sites have been dated, compared to $34 \%$ of Neolithic pit-and-spread complexes. Rarer still are pit-and-spread complexes where multiple dates are available from short-lived samples. An unknown in this analysis is the degree to which pits are undated on multi-period sites, which is almost certainly an additional source of bias. Neolithic houses are further emphasized in the radiocarbon record (e.g. Figure 9) by research interests surrounding dating the neolithisation of the island (Cooney et al. 2011), and efforts to understand the agricultural practices of the period (McClatchie et al. 2014). A somewhat hidden fact is that pit complexes are found during development-led fieldwork far more frequently than 
any other type of Neolithic site, yet they are under-studied, and important segments of the archaeological settlement narrative may be missing as a result (cf. Smyth 2012).

There are, however, some geographical patterns in the data that seem significant despite these problems. Central regions in Ireland have neither Early Neolithic megalithic monuments nor settlements, although there are some undated sites (shown on Fig. 4), which should be a priority for future work. Excavation bias can be ruled out, as many Early Bronze Age sites are known from the Midlands (Fig. 7), as are numerous Middle and Late Bronze Age settlements (Ginn 2011). These regions may simply have been unsettled or poorly settled in the Early Neolithic. Whilst the palaeoecological record from these areas suggests they were not devoid of human impact at this time, the scale and precise timing of these palaeoecological events is difficult to ascertain (Whitehouse et al. 2014; Barratt et al. in prep.).

Turning to the Early Bronze Age pit-and-spread complexes, similar biases probably affect their known numbers, although research is at an early stage with respect to undated sites of this period. If the dated sites are representative of the overall number, then Early Bronze Age pit complexes are found with an even greater frequency than Neolithic ones. Most dated pits contained Beaker or Food Vessel pottery. In contrast, burnt mounds rarely contain any artefactual material (Ó Néill 2009). Pits containing pottery may be overrepresented in the radiocarbon narrative, compared to less frequently dated aceramic depositions, which may in turn create a bias toward certain types of site and points in time where pottery was more commonly used.

That said, the frequency of pit complexes probably remains a more useful tool than burials or burnt mounds to make a comparison between Early Bronze Age and Neolithic settlement intensity. Burnt mounds are highly visible extant sites, and also tend to be recognized quickly during development-led excavations, due to the enormous quantity of burnt material they contain. Although Early Neolithic burnt mounds in Ireland are relatively well-dated, the only well-dated burnt mound dating to the Early Bronze Age is Cahircalla Mor, Co. Clare (Taylor 2006). In addition, one date on unburnt hazelnut shell is available from Rathmullan 3, Co. Meath (Irish Archaeological Consultancy, personal communication, June 2013). At face value, the lack of quality dating evidence from these sites seems exasperating, but there are perceived costs and difficulties associated with isolating suitable short-lived dating material (such as seeds or nutshells) from samples rich in wood charcoal.

Conversely, cist burials have been very well dated, thanks to the nature of these deposits and the availability of AMS radiocarbon dating (especially new AMS developments with respect to cremated bone) (Brindley 2007; Lanting and Brindley 1998-though see Snoeck et al. (2014) for a cautionary note). The absolute number of known cist burials is not comparable to other sites as the numbers reflect the circumstances of discovery-many cists were found by agricultural workers during field drainage operations (Waddell 1970).

Future work will have the opportunity to address some of these issues. A priority should be the dating and analysis of pit-and-spread complexes, especially in midland areas where chronological data are lacking (Fig. 4), not least to test the hypothesis that many of these sites date to the Early-Middle Neolithic transitional period, Middle Neolithic I, 3600-3400 cal BC. Thorough dating of burnt mounds is also required if their relationship with Early Bronze Age settlements and burials is to be understood.

\section{Chronology and Discontinuity, or Boom and Bust?}

The biases discussed above must be somehow addressed if the archaeological record can be read as a demographic proxy or a measure of changing economic practices (e.g. 
Shennan et al. 2013; Stevens and Fuller 2012). The first problem is the radiocarbon old wood effect. In Ireland, the precisely dated Neolithic 'house horizon' offers a useful chronological datum for assessing radiocarbon dates from the whole period. The old wood effect has confused the estimation of the start of the Neolithic in Ireland, which until recently was thought to date to around 4000 cal BC (cf. Cooney 2000a; Cooney et al. 2011; Whitehouse et al. 2014). Potentially misleadingly, the animated map (Fig. 8) and the summed radiocarbon dates (Fig. 9) indicate large numbers of charcoal samples dating to the period 4000-3700 cal BC, themselves deriving from various contexts often within or associated with rectangular houses. Also contributing to this pattern are, for example, charcoal dates from Carrowmore (Burenhult 1984) and Magheraboy (Danaher 2007). In our database, 41 of the 103 dated charcoal samples from these structures have been identified to species, but no particular tree or shrub species predominates. At rectangular houses, approximately $50 \%$ of radiocarbon dates on charcoal are too early when compared to Bayesian models of short-lived samples from these sites, emphasizing the problems of radiocarbon dating charcoal. That said, workers are usually very careful to select charcoal sapwood and short-lived elements for dating, and indeed the effect is barely noticeable for other contexts, such as Early Bronze Age burials. It is possible that various archaeological and ecological factors combine to accentuate the old wood problem in the context of landnam. For example, the errant dates may reflect the old growth of the substantial timbers which were, presumably, used in the buildings' construction (Smyth 2006, 2007). This phenomenon is potentially amplified by the relatively easy access to dead, seasoned timber in primeval forest ecosystems during the early landnam phases (cf. Whitehouse 2006). Clearly much more work is needed to better understand the old wood charcoal vectors and their effects on radiocarbon dates, which may produce a more nuanced understanding of human-environment interactions in a time period pivotal to the fate of both the European primeval forest and the humans who first modified it so radically.

Problems in charcoal dating aside, there are several chronological patterns of great interest. Pits and spreads, which are manifest for many archaeological periods, are widely recognized to be the result of settlement activity, as the pits contain material such as lithic debris, pottery sherds, plant remains and animal bone. Consider a 'null hypothesis' suggesting that, all things being equal, the rate of pit deposition was even throughout prehistory. The null hypothesis predicts that the number of known pits attenuates with age, due to the decay channel provided by erosion and diagenesis (cf. Surovell et al. 2009). Real-world archaeological signals are, of course, infinitely more complex than this, due to the research biases discussed above, fluctuating prehistoric population levels, and changes in behavioural patterns that affect the deposition of such material in the ground. Nevertheless, a comparison of the data with this null hypothesis is useful, as it provides a firmer basis for assessing how fluctuating levels of archaeological activity can be related back to the changes in behaviour and activity.

This model can be formalized using Surovell and colleagues' (2009) power function with the summed radiocarbon probability distribution function for pit-and-spread sites (Fig. 10). The results again show a highly significant rate of deposition between 3700 and $3300 \mathrm{cal}$ BC and an ensuing Middle Neolithic hiatus. It must be stressed that the model cannot, of course, control for changes in practice, such as the shift away from timber as a building material during the Neolithic, and therefore using it as a simple analogue of population is misleading. It remains useful, however, because it provides a formal way to calibrate observed differences in site formation rates between periods. In this example, the rate of pit formation is twice as high in the Early Bronze Age as in the Late Neolithic, if we take the radiocarbon dates at face value. After applying the power function, the rate of pit 


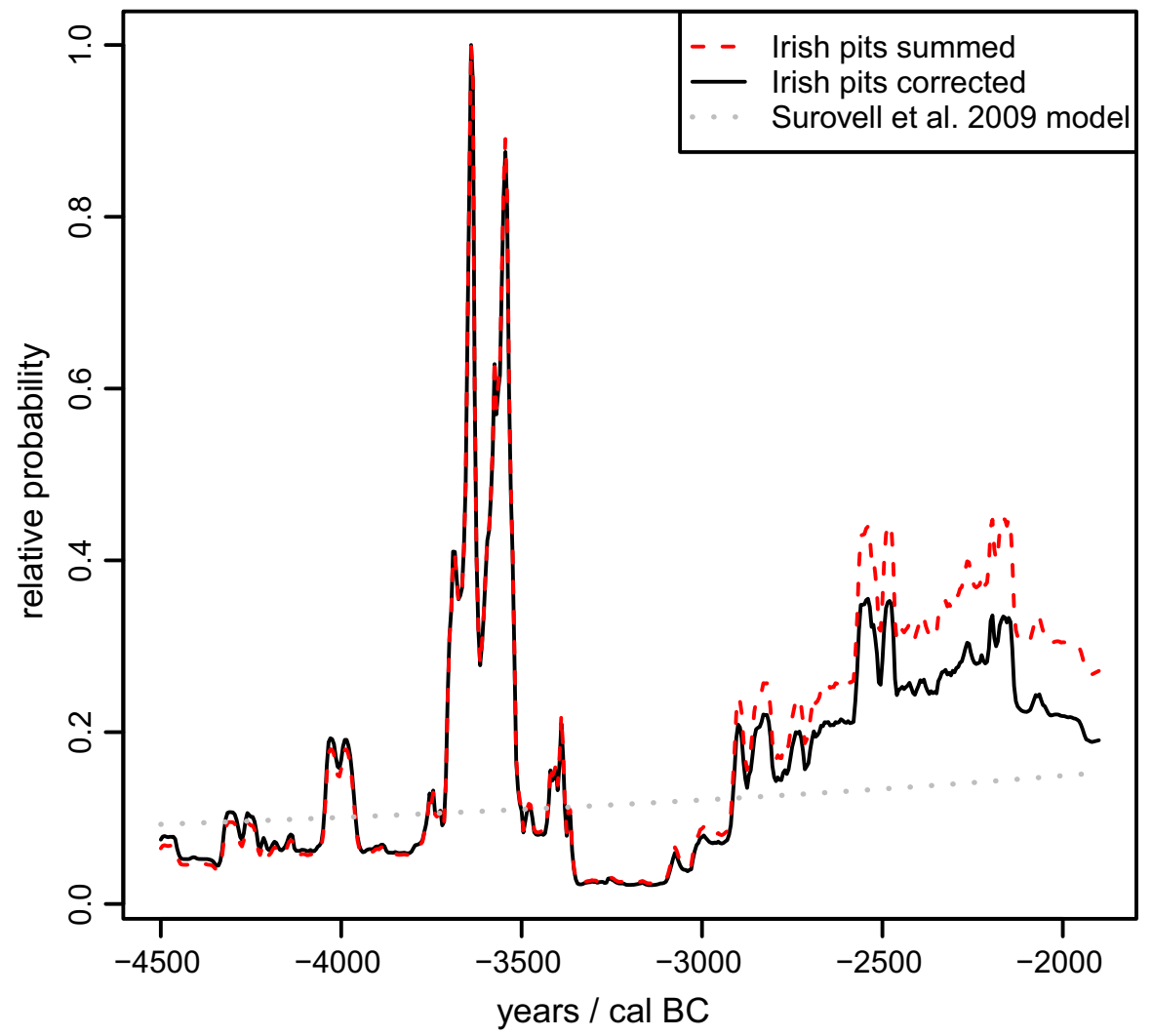

Fig. 10 Summed probability distribution for Irish pits corrected for taphonomic loss of material. Surovell and colleagues' model is an estimate of the rate of loss of archaeological sediment, empirically derived from pyroclastic radiocarbon data

formation is only $50 \%$ greater. Indeed, the relative probability of the function is similar around $3450 \mathrm{cal} \mathrm{BC,} 2900 \mathrm{cal} \mathrm{BC}$ and $1900 \mathrm{cal} \mathrm{BC}$. These three points in time provide examples of relatively 'normal' levels of activity; departures from this norm warrant explanations in terms of changes or differences in behaviour or (more cautiously) population level.

There is, however, some scope for testing the population hypotheses by turning to ancient DNA work, specifically the evidence for inbreeding presented by runs of homozygosity (MacLeod et al. 2013). This analysis provides insight into the ancestry of an individual by identifying identical parts of the genome inherited from both parents, and can identify both recent endogamy and ancestral population restrictions. Recent work by Cassidy et al. (2016) has analysed runs of homozygosity in the genomes of two ancient Irish individuals dating to c. 3300 cal. BC (Ballynahatty '1855') and 1800 cal. BC (Rathlin Island) and found little evidence for small, restricted population sizes-'genetic bottlenecks'-in the ancestry of either. Presuming that the ancestors of the Ballynahatty individual were resident in Ireland, the lack of settlement evidence from c. $3300 \mathrm{cal}$ BC does not therefore imply small population-rather that a relatively healthy ancient population has left no archaeological traces other than their burial monuments. This does not exclude 
the possibility that population levels fluctuated during the course of the Neolithic, but it does illustrate the problems of taking the archaeological record too literally in terms of demographic modelling - in particular, that low activity in large samples of radiocarbon dates really is evidence for an absence of people (pace Timpson et al. 2014). The hiatus in pit deposition between 3300 and $3000 \mathrm{cal} \mathrm{BC}$ is nonetheless a significant finding, implying that the archaeological coverage of the Middle Neolithic in Ireland is incomplete, despite the rich and well-researched evidence for Middle Neolithic burial, ritual and art. Of course, the division between settlement and burial context need not imply a similar dichotomy in domestic and ritual behaviour (cf. Bradley 2005). Unfortunately, of those tombs that have been excavated, few signals of domestic activity emerge. Cereal remains from Baltinglass and Knowth date to earlier, pre-tomb occupation phases before $3400 \mathrm{cal} \mathrm{BC}$, although the Baltinglass tomb had an earlier construction date altogether (Schulting et al. submitted).

The points in time where archaeological signals proliferate are as problematic in terms of population modelling as those where settlement is absent. Between 3750 and $3500 \mathrm{cal}$ $\mathrm{BC}$, for example, the settlement record in Ireland points to much activity. Bayesian models of the dates from the earlier Neolithic pit complexes have identified that their use as active settlement sites commenced between 3710 and $3655 \mathrm{cal} \mathrm{BC}$ and ended between 3515 and 3460 cal BC (Schulting 2011; Whitehouse et al. 2014). The significance of this discovery is reinforced by a number of recent publications that have pointed out high levels of activity - a boom - among all domestic and burial contexts at this time, in both Ireland and Britain, echoing a pattern in radiocarbon data from other European regions (Shennan and Edinborough 2006; Bayliss and Whittle 2007; Whittle et al. 2011; Schulting et al. 2012; Shennan et al. 2013).

Extrapolating from the relatively small proportion of Ireland's surface that has been subject to archaeological investigation, many thousands-perhaps tens of thousands-of similar sites must lie undiscovered in the countryside. The high frequency of Early Neolithic sites, contrasted with the low frequency of Late Mesolithic sites, is explained most simply by large-scale movement of people to Ireland at the start of the Neolithic, even without considering the fundamental changes in economy and monumentality that occurred in tandem with this process. Analysis of ancient DNA homozygosity at Ballynahatty supports this view (Cassidy et al. 2016). It is possible that several such episodes of neolithisation took place simultaneously, or somehow overlapped in such a way that the archaeological record now contains entangled traces of different or competing, but ultimately all 'Neolithic' groups of people. Many recurring themes in Early Neolithic Britain and Europe are present in Ireland around $3700 \mathrm{cal}$ BC-rectangular houses echoing aspects of LBK architecture (Smyth 2010, 2014); early passage tombs expressing an Atlantic tradition already centuries old, of likely Breton origin (Sheridan 2010); and in northern Ireland and southern Scotland, a shared megalithic paradigm (e.g. Collins 1973; Sheridan 2004).

At face value, the Irish radiocarbon data indicate that this initial flourishing was short lived, and that there was a sudden 'bust' at 3500 cal BC (Fig. 9). However, by focussing upon pits in the analysis (Fig. 10), we can control some of the bias caused by the high visibility of rectangular houses in the archaeological record. Although there is still a pronounced peak in activity ending around $3500 \mathrm{cal} \mathrm{BC}$, which coincides with a steep region of the calibration curve (Reimer et al. 2013), activity does not reach a minimum until 3300 cal BC. A decline in activity, over some 200 years or 10 human generations, would be a more realistic characterisation of the overall pattern.

The balance of information suggests the population in Early Neolithic Ireland, at least by $3700 \mathrm{cal} \mathrm{BC}$ was large-thousands of sites were in use at the same time, spread over 
much of the island. The declining levels of activity seen between 3500 and 3300 cal BC are difficult to explain without invoking a change in human behaviour across the island that led to the persistence of burial in the archaeological record, but the absence of settlement. Whether or not this was also the consequence of a reduced population size is a matter of debate, but another perspective on this puzzle can be acquired from palaeoecological data. Efforts to synthesize palynological investigations of the Irish landscape are at an advanced stage, and initial results suggest that vegetation changes commensurate with reforestation occur in tandem with the degradation of the settlement signal, beginning around $3500 \mathrm{cal}$ BC (Whitehouse et al. 2014; Barratt et al. in prep.). We can therefore begin to suggest that the hiatus in settlement archaeology really does reflect a more general lack of human activity, although from the genetic evidence from Ballynahatty (Cassidy et al. 2016) it is unlikely that the population 'collapsed' completely.

Prominent burials and elusive settlement signals have analogues with other points of European prehistory, such as the Corded Ware culture of Central Europe (Müller et al. 2009). Thus, far from seeing a boom and bust of prehistoric populations at this time, we see-through contextualising the archaeological data-a record of cultural change, when settlement and economic activities were moderated, and where burial and megalithic monuments achieved greater prominence.

The Late Neolithic in Ireland underwent a reversal of Middle Neolithic trends, which is similarly difficult to interpret. The sudden re-emergence of the settlement signal after 3000 cal BC implies some indication that a demographic event had occurred, or that there was a widespread and rapid change in behaviour, especially as during this period Grooved Ware pottery was introduced from Britain, perhaps from Orkney (Brindley 1999; Sheridan 2004). The term 'rapid' is of course relative-it is unknown whether the changes happened over a century or a generation or less, as the radiocarbon record for the sites in question as yet lacks this level of resolution. Nevertheless, in archaeological terms, the term does seem applicable.

The pit deposition rate during the Late Neolithic and Early Bronze Age shows only gradual increase beyond the rate that would be observed on the basis of taphonomy alone. As with Britain, a potential mass immigration of people into Ireland in the Chalcolithic/ Early Bronze Age-bringing with them the distinctive material culture and burial practices of that time (de Valera and Ó Nualláin 1982; Eogan 1991)—has been postulated. An alternative view is that the Bronze Age transition happened as a result of increasing contacts with Britain and Europe, and was predicated on an emerging indigenous élite (Cooney and Grogan 1994). In the analysis presented here, because the rate of pit deposition gradually increased from the Late Neolithic period onwards at a rate that only slightly exceeds the expected increase due to taphonomy, a relatively stable and slowgrowing human population during this time is inferred. This view contrasts with the marked increase of the archaeological visibility of burials in the centuries following 2200 cal BC. A stable population supports the opinion that large or sudden population influxes did not occur, although it remains possible that immigration occurred at a rate that matched emigration and/or decline in those groups whose ancestry had been established on the island for a longer period-conquest rather than colonization perhaps. Ancient DNA analysis of three Early Bronze Age individuals found in cist burials on Rathlin Island has demonstrated that they had few or no Middle Neolithic ancestors; in addition, runs of homozygosity in one of these individuals imply that there were no bottlenecks in that ancestry either, all of which points to descent from a relatively large incoming population, rather than an élite group of outsiders or an acculturated Neolithic progeniture (Cassidy et al. 2016). Returning briefly to the animated map (Fig. 8), it is noteworthy that spatial and 
temporal trends in the cist burials of the period suggest that the tradition probably originated at c. $2200 \mathrm{cal} \mathrm{BC}$ in the south of the island, becoming more widespread soon thereafter. The combined insight from archaeological and chronological data and ancient DNA provides a fresh perspective on how cultural change in prehistory occurred. It is also interesting that despite a boom in burial, a proliferation of other site-types such as burnt mounds, and the diversification observed in the material culture of the period, the expected commensurate increase in pit deposition is not observed. This finding also serves to reinforce the need to contextualise archaeological data in summed probability analyses.

\section{Conclusions}

In 1989, the absolute chronology of Ireland's prehistory was based on 109 radiocarbon dates from 61 sites (O'Kelly 1989, pp. 347-352). In this study, the figure stands at 4679 dates from 1536 sites. These numbers are biased towards the Neolithic period, and the true figures are probably much higher (e.g. Armit et al. 2013). The amount of raw archaeological data available for Ireland has substantially increased, thanks to development-led excavation. The challenge of how to plumb these data for knowledge of the human past can be met by the development of appropriate information systems and analytical tools, such as the methods described in this paper and elsewhere (e.g. Surovell et al. 2009; Shennan et al. 2013; Stevens and Fuller 2012; Armit et al. 2013, Kerr and McCormick 2013). Many of these methods are applicable to other regions and countries working through a similar backlog of excavated sites (Bradley 2012). We have concentrated upon chronological and geographical dimensions in this paper, although a more in-depth study of prehistoric life could also integrate scientific approaches, such as palaeoecology, lipid analysis and other analyses of artefactual material, stable isotope analysis and other biomolecular studies on ancient animal and human bones. Ancient DNA analysis will be particularly useful in testing hypotheses concerning incoming populations, as the pioneering work by Cassidy et al. (2016) has shown. In the developer-led sector in Ireland, none of these techniques has been extensively applied, although this situation is slowly changing with respect to palaeoecology, stable isotopes and lipid analyses (e.g. Murphy et al. 2010; Stuijts et al. 2010; Whitehouse et al. 2014; Schulting et al. 2012; Schulting et al. 2016; Smyth and Evershed 2015).

Despite the wealth of data, gaps and discontinuities in the archaeological record remain, although some of these gaps are as informative as they are problematic. The Irish Neolithic gets rather more enigmatic with time, with the Early Neolithic period being relatively visible archaeologically, and attracting a high level of research interest. The recent discovery that there is only scant evidence for recognisably 'Neolithic' activity in Ireland before c. $3750 \mathrm{cal} \mathrm{BC}$ has important ramifications, and many of the ideas postulated in this paper depend on this revised chronology. As discussed above, the old wood effect is particularly problematic for Early Neolithic Ireland, and has confused the dating of the earliest Neolithic in Ireland. McSparron's (2008) demonstration of the short period of use for rectangular houses is therefore of key importance; so too is the increasing awareness of the episodic nature of other types of site (McSparron 2003, 2008; Cooney et al. 2011; Schulting et al. 2012; Whitehouse et al. 2014).

Modern-day development pressures have revealed clusters of Neolithic houses around the northern and eastern coasts-foci of settlement in the Early Neolithic. These newlydiscovered clusters coincide with funerary landscapes, and these places seem 
geographically poised to be likely points of contact with Britain-perhaps reflecting the original points of entry for people bringing with them the new plants, animals and ways of thinking which together constituted the Neolithic. Due to an absence of data, and perhaps a reluctance to broach politically-loaded debates (Stout 1996), Irish archaeology has been generally unable to meaningfully investigate the prehistoric dimensions of Ireland's cultural and demographic relationships with Britain and elsewhere. We have taken this first step of exploring prehistoric demographics in Ireland with a view to future exploration of both its position on the periphery of Europe, and its links to its neighbours.

The Early to Middle Neolithic transition (Middle Neolithic I) is a key time period in both Ireland and Britain (cf. Bishop 2015; Stevens and Fuller 2012). Evidence for settlement is frequently found, but has received less attention both from researchers and from those working in development-led archaeology. Hence fewer sites have been dated, and understanding of the burial traditions of the period is correspondingly hazy. The pitand-spread complex has emerged as an important site-type warranting much greater research emphasis both in the field and in the laboratory. Notwithstanding these issues, by considering the large number of sites that date to the period, Ireland supported 10-20 generations of significant numbers of people, from the manifestation of Neolithic sites after $3750 \mathrm{cal}$ BC, until 3500-3400 cal BC, when the archaeological record undergoes significant changes.

Despite archaeological monitoring at thousands of sites in Ireland, and the numerous prehistoric settlements that have been found as a result, secure, well-dated evidence of Middle Neolithic II settlement during the period 3400-3000 cal BC is still to be discovered. This challenges our view of overall lifestyles during the era of the developed passage tomb. We can only speculate about the nature of settlement during this period, as there is so little evidence, and neither pastoralism nor arable agriculture offers a model for the economy of the period that fits the available archaeological and environmental data. There are no directly dated cereals from Middle Neolithic II, so evidence of a cereal economy, if there was one, is absent (McClatchie et al. 2014). Investigation of the faunal remains from the period is also hampered by a lack of suitable material. The limited stable isotope evidence on human remains for this period does not suggest a significant return to marine resources (Ditchfield 2014; Schulting et al. 2012, 2016), but nor does it exclude a decline in the use of cereals or other plants in favour of animals. Analyses of lipids absorbed in Irish pottery indicate dairying was of considerable importance throughout the Neolithic (Cramp et al. 2014; Smyth and Evershed 2015; but note that fewer vessels have been analysed from the later period). This is not incompatible with a mobile or semi-nomadic mixed pastoral economy for Middle Neolithic Ireland, although it should be noted that there is no contrast between Early, Middle and Late periods in this regard. Pastoralism, which seems to offer one potential explanation for the lack of cereals, has been applied to the Middle Neolithic in Britain (Stevens and Fuller 2012; although see also Bishop 2015). However, in Ireland, the commensurate impact on the landscape is not seen in palaeoecological records-many pollen diagrams from this period indicate a phase of less extensive use of the landscape than would be expected under pastoralism, with evidence for forest regeneration in many parts of Ireland, especially westerly areas (O'Connell and Molloy 2001; Whitehouse et al. 2014). The palaeoclimatic context of this period is also interesting, given that the end of the Holocene Thermal Maximum led to a sustained period of lower temperatures and wetter conditions in Ireland and elsewhere in northern Europe (Steig 1999; Roland et al. 2015).

The sudden increase in activity in the Early Neolithic was echoed, to a degree, at the start of the Late Neolithic. New pottery forms and site types-Grooved Ware and henges- 
were introduced from Britain, although this episode is only one of many hints of reciprocal influence between Ireland and Scotland from the Middle Neolithic period onwards (Schulting et al. 2008; Sheridan 2004).The chronological relationship between Britain and Ireland, in terms of the timing of these influences, is still uncertain and resolving this issue will be a key research question for the immediate future. Furthermore, despite recent progress in ancient DNA, the small sample of Neolithic and Bronze Age individuals analysed by Cassidy et al. (2016) does not inform about potential Late Neolithic and/or Chalcolithic population movements to Ireland-in short, much more work on this front is needed. It remains tempting to postulate that this work, when combined with well-dated archaeological data from Ireland and northern Britain, will reveal clear evidence that there was continual movement of people between the two islands-a process probably as widespread in prehistory as it was during recorded history (e.g. Anderson 1982) and indeed in the present day.

In Ireland, now that burial chronology is becoming much better understood (Brindley 2007; Schulting et al. 2008), the whole of the third millennium BC can be seen to have been characterized by numerous episodes of rapid change in material culture, ceremonial behaviour and burial tradition. Set against this, however, is the steady rate of pit deposition, and settlement types in many ways continue to resemble those of the Early-Middle Neolithic transition. However, new site-types such as stone and timber circles, henges and burnt mounds were also manifest, evidencing wide-ranging successive and contemporary beliefs and practices, some imported and others insular developments. In the near future, we hope that better-resolved observations of this key timeframe can be made through the analysis of archaeological datasets.

The boom-and-bust model has been successful in illustrating that change in prehistory occurred-at least on occasion-at a much greater tempo than has been traditionally acknowledged, and indeed various patterns in the Irish data suggest periods of rapid change in the rates of creation of certain site-types and deposition of materials. It seems plausible that some of these changes were related to demographic events, albeit viewed through a heavy fog of bias. Indeed, whilst it is clear that there are phases in some aspects of the archaeological record, there may also be simultaneous booms, which express themselves differently-for example the shift of focus towards burial in the archaeological record in Ireland around $3400 \mathrm{cal} \mathrm{BC}$. Therefore, without contextualizing archaeological data, such boom-and-bust interpretations of summed probability distributions are an over-simplification, and misleading.

An unknown, despite advances in radiocarbon dating and Bayesian modelling, is the way in which these events were witnessed by the contemporary human population. Changes that seem relatively rapid in the archaeological record may have taken several human generations to fully express themselves, and any awareness of such change must have been made in the context of on-going adaptations to a 'real world', where environmental, economic and demographic interests compete, often in a state of dynamic equilibrium but occasionally breaking down altogether.

These glimpses of a more dynamic past are a recent development in prehistoric archaeology, and have been made possible by the availability of increasingly large datasets, as well as by new approaches to their analysis (Shennan 2013). Development-led archaeology in Ireland, sampling the landscape in a rather less biased fashion than is usually the case, has achieved much in redressing the traditional illusiveness of prehistoric settlement evidence, and it is this accomplishment that we wish to celebrate. As the rate of excavation work on the island now increases in line with its economic recovery we may expect frequent new discoveries, some of which will serve to fill the gaps in knowledge 
that still exist at the time of writing, especially if systematic programmes of radiocarbon dating are instigated, together with a renewed appreciation of the importance of careful sample selection. The combination of contextual and chronological archaeological data (e.g. Figure 9) illustrates just how dynamic past societies were, and for the first time we can more clearly identify the points in time and space where the changes were at their greatest. In Ireland, the points at the start and end of the Middle Neolithic period (c. 3400 and 3000-2900 cal BC) are perhaps the most intriguing of all, and these deserve some of the research attention usually lavished upon the Early Neolithic.

Acknowledgments The work reported here was funded by the Heritage Council, Republic of Ireland, INSTAR Programme 2008-2010, for 'Cultivating Societies: Assessing the Evidence for Agriculture in Neolithic Ireland' (Ref: 16682, to Whitehouse, Schulting, Bogaard and McClatchie). The following organisations and individuals are thanked for providing access to unpublished site reports and radiocarbon data: ACS Ltd; ADS Ltd; Aegis Archaeology Ltd; AML Archaeology Ltd; Arthur ApSimon; CAF, Queen's University Belfast; Robert Chapple; CRDS Ltd; Dept of Archaeology, University College Cork; Eachtra Archaeological Projects Ltd; Headland Archaeology Ltd; IAC Ltd; Margaret Gowen and Co. Ltd; NAC Ltd; National Roads Authority; School of Archaeology, University College Dublin; Stafford McLoughlin Archaeology Ltd; TVAS Ireland Ltd; Valerie J. Keeley Ltd. Discussions with various colleagues greatly improved the paper: in particular we thank Neil Carlin, Russell McLaughlin, Jim Mallory and Jessica Smyth for their helpful comments and ideas, as well as Alison Sheridan and a second, anonymous reviewer.

Open Access This article is distributed under the terms of the Creative Commons Attribution 4.0 International License (http://creativecommons.org/licenses/by/4.0/), which permits unrestricted use, distribution, and reproduction in any medium, provided you give appropriate credit to the original author(s) and the source, provide a link to the Creative Commons license, and indicate if changes were made.

\section{References}

Anderson, M. O. (1982). Dalriada and the creation of the Kingdom of the Scots. In D. Whitelock, R. McKetterick, \& D. Dumville (Eds.), Ireland in Early Medieval Europe: Studies in memory of Kathleen Hughes (pp. 106-132). Cambridge: Cambridge University Press.

Armit, I., Swindles, G., \& Becker, K. (2013). From dates to demography in later prehistoric Ireland? Experimental approaches to the meta-analysis of large ${ }^{14} \mathrm{C}$ data-sets. Journal of Archaeological Science, 40, 433-438.

Bamforth, D. B., \& Grund, B. (2012). Radiocarbon calibration curves, summed probability distributions, and early Paleoindian population trends in North America. Journal of Archaeological Science, 39, 1768-1774. doi:10.1016/j.jas.2012.01.017.

Barclay, A., \& Bayliss, A. (1999). Cursus monuments and the radiocarbon problem. In A. Barclay \& J. Harding (Eds.), Pathways and ceremonies: The cursus monuments of Britain and Ireland (pp. 11-29). Oxford: Oxbow.

Barclay, G. J., Brophy, K., \& MacGregor, G. (2002). Claish, Stirling: An early Neolithic structure in its context. Proceedings of the Society of Antiquaries of Scotland, 132, 65-137.

Barker, G. (1985). Prehistoric farming in Europe. Cambridge: Cambridge University Press.

Bayliss, A., \& O'Sullivan, M. (2013). Interpreting chronologies for the Mound of the Hostages, Tara and its contemporary contexts in Neolithic and Bronge Age Ireland. In M. O'Sullivan, C. Scarre, \& M. Doyle (Eds.), Tara-from the past to the future: Towards a new research agenda (pp. 26-104). Dublin: Wordwell.

Bayliss, A., \& Whittle, A. (Eds.) (2007). Histories of the dead: Building chronologies for five southern British long barrows. Cambridge Archaeological Journal, 17(S1), 1-147.

Behre, K.-E. (2007). Evidence for Mesolithic agriculture in and around central Europe? Vegetation History and Archaeobotany, 16, 203-219.

Bergh, S., \& Hensey, R. (2013). Unpicking the chronology of Carrowmore. Oxford Journal of Archaeology, 32, 343-366. doi:10.1111/ojoa.12019.

Bishop, R. R. (2015). Did Late Neolithic farming fail or flourish? A Scottish perspective on the evidence for Late Neolithic arable cultivation in the British Isles. World Archaeology, 47(5), 834-855. 
Bradley, R. (2005). Ritual and domestic life in prehistoric Europe. London: Routledge.

Bradley, R. (2006). Northern Scottish henge project, Aberdeenshire (Kintore parish), research excavation. Discovery and Excavation in Scotland, 7, 19-20.

Bradley, R. (2007). Houses, bodies and tombs. Proceedings of the British Academy, 144, 347-355.

Bradley, R. (2012). Postscript: Recorded time. In C. Haselgrove, L. Webley, R. Bradley, \& M. V. Linden (Eds.), Development-led archaeology in Northwest Europe (pp. 173-175). Oxford: Oxbow.

Brindley, A. (1999). Irish Grooved Ware. In R. Cleal \& A. MacSween (Eds.), Grooved Ware in Britian and Ireland (pp. 23-25). Oxford: Oxbow.

Brindley, A. (2007). The dating of food vessels and urns in Ireland. Galway: Department of Archaeology, National University of Ireland.

Brindley, A., \& Lanting, J. (1998). Radiocarbon dates for Irish trackways. Journal of Irish Archaeology, 9, $45-67$.

Brindley, A., Lanting, J., \& Van Der Plicht, J. (2005). Radiocarbon-dated samples from the Mound of the Hostages. In M. O'Sullivan (Ed.), Duma na nGial: The Mound of the Hostages, Tara (pp. 281-296). Dublin: Wordwell \& University College Dublin.

Bryson, R. U., Bryson, R. A., \& Ruter, A. (2006). A calibrated radiocarbon database of late Quaternary volcanic eruptions. Earth Discussions, 1, 123-124.

Burenhult, G. (1984). The archaeology of Carrowmore. Theses and Papers in North European Archaeology, 14. Stockholm: Institute of Archaeology, University of Stockholm.

Burl, A. (2000). The stone circles of Britain, Ireland, and Brittany. New Haven: Yale University Press.

Carlin, N. (2011a). Into the West: Placing Beakers within their Irish contexts. In A. M. Jones \& G. Kirkham (Eds.), Beyond the core: Reflections on regionality in prehistory (pp. 87-100). Oxford: Oxbow.

Carlin, N. (2011b). A proper place for everything: The character and context of beaker depositional practice in Ireland. Ph.D. dissertation, University College Dublin, Dublin.

Cassidy, L. M., Martiniano, R., Murphy, E., Teasdale, M. D., Mallory, J., Hartwell, B., et al. (2016). Neolithic and Bronze Age migration to Ireland and establishment of the insular Atlantic genome. Proceedings of the National Academy of Sciences, 113(2), 368-373. doi:10.1073/pnas.1518445113.

Chapple, R. M. (2008). The absolute dating of archaeological excavations in Ulster carried out by Northern Archaeological Consultancy Ltd, 1998-2007. Ulster Journal of Archaeology, 67, 153-181.

Chaffey G., Barclay, A., \& Pelling, R. (2016). Horton, Kingsmead Quarry (Vol. 1). Wessex Archaeology.

Childe, V. G. (1925). The dawn of European civilization. London: Routledge \& Kegan Paul.

Collins, A. E. P. (1973). A re-examination of the Clyde-Carlingford tombs. In G. Daniel \& P. Kjærum (Eds.), Megalithic graves and ritual (pp. 93-103). Copenhagen: Jutland Archaeological Society.

Collins, T., \& Coyne, F. (2003). Fire and water: Early Mesolithic cremations at Castleconnell, Co., Limerick. Archaeology Ireland, 17(2), 24-27.

Contreras, D. A., \& Meadows, J. (2014). Summed radiocarbon calibrations as a population proxy: A critical evaluation using a realistic simulation approach. Journal of Archaeological Science. doi:10.1016/j.jas. 2014.05.030.

Cooney, G. (1983). Megalithic tombs in their environmental setting: A settlement perspective. In T. ReevesSmith \& F. Hamond (Eds.), Landscape archaeology in Ireland, British Archaeological Reports 116 (pp. 179-194). Oxford: BAR.

Cooney, G. (1999). A boom in Neolithic houses. Archaeology Ireland, 13, 13-16.

Cooney, G. (2000a). Landscapes of Neolithic Ireland. London: Routledge.

Cooney, G. (2000b). Recognising regionality in the Irish Neolithic. In A. Desmond, G. Johnson, M. McCarthy, J. Sheehan, \& E. Shee Twohig (Eds.), New agendas in Irish Prehistory: Papers in commemoration of Liz Anderson (pp. 49-65). Bray: Wordwell.

Cooney, G., Bayliss, A., Healy, F., Whittle, A., Danaher, E., Cagney, L., et al. (2011). Ireland. In A. Whittle, F. Healy, \& A. Bayliss (Eds.), Gathering time: Dating the early Neolithic enclosures of southern Britain and Ireland (pp. 562-681). Oxford: Oxbow.

Cooney, G., \& Grogan, E. (1994). Irish Prehistory: A social perspective. Dublin: Wordwell.

Cooney, G., \& Mandal, S. (1998). The Irish Stone Axe Project Monograph I. Bray: Wordwell.

Cramp, L. J. E., Jones, J., Sheridan, A., Smyth, J., Whelton, H., Mulville, J., et al. (2014). Immediate replacement of fishing with dairying by the earliest farmers of the northeast Atlantic archipelagos. Proceedings of the Royal Society B: Biological Sciences. doi:10.1098/rspb.2013.2372.

Crombé, P., \& Robinson, E. (2014). ${ }^{14} \mathrm{C}$ dates as demographic proxies in Neolithisation models of northwestern Europe: A critical assessment using Belgium and northeast France as a case-study. Journal of Archaeological Science. doi:10.1016/j.jas.2014.02.001.

Danaher, E. (2007). Monumental beginnings: The archaeology of the N4 Sligo inner relief road. NRA Scheme Monographs 1. Dublin: National Roads Authority. 
de Valera, R., \& Ó Nualláin, S. (1982). Survey of the megalithic tombs of Ireland, Volume IV: Counties Cork, Kerry, Limerick and Tipperary. Dublin: Stationery Office.

Ditchfield, P. (2014). Stable isotope analysis. In A. Lynch (Ed.), Poulnabrone, Co. Clare: Excavation of an Early Neolithic portal tomb. Archaeological Monograph Series (pp. 86-92). Dublin: Department of Arts, Heritage and the Gaeltacht.

Doody, M. (2008). Final report: Lough Feedora, Co. Tipperary. N8 Cashel to Mitchelstown Road Improvement Scheme. Unpublished excavation report, Margaret Gowen \& Co.

Dowd, M., \& Carden, R. F. (2016). First evidence of a Late Upper Palaeolithic human presence in Ireland. Quaternary Science Reviews, 139, 158-163. doi:10.1016/j.quascirev.2016.02.029.

Dunne, C. M. (2008). Appendix 3: Report on the ceramic assemblage from Liscolman, County Antrim. In Gilmore, S. (Ed.), Straidbilly, Liscolman, County Antrim. Unpublished excavation report, Northern Archaeological Consultancy.

Eogan, G. (1991). Prehistoric and early historic cultural changes at Brugh na Bóinne. Proceedings of the Royal Irish Academy, 91C, 105-132.

Fairweather, A. D., \& Ralston, I. B. M. (1993). The Neolithic timber hall at Balbridie, Grampian Region, Scotland: The building, the date, the plant macrofossils. Antiquity, 67, 313-323.

Feeser, I., \& Furholt, M. (2013). Ritual and economic activity during the Neolithic in Schleswig-Holstein, northern Germany: An approach to combine archaeological and palynological evidence. Journal of Archaeological Science, 51, 126-134. doi:10.1016/j.jas.2013.01.021.

Gilmore, S. (2008). Straidbilly, Liscolman, County Antrim. Unpublished excavation report, Northern Archaeological Consultancy.

Ginn, V. (2011). The fusion of settlement and identity in dispersed and nucleated settlements in Bronze Age Ireland. Journal of Irish Archaeology, 20, 27-44.

Grogan, E. (1996). Neolithic houses in Ireland. In T. Darvill \& J. Thomas (Eds.), Neolithic houses in northwest Europe and beyond. Monograph Series 57 (pp. 41-60). Oxford: Oxbow.

Gronenborn, D. (2003). Migration, acculturation and culture change in western temperate Eurasia, 6500-5000 cal BC. Documenta Praehistorica, 30, 79-91.

Hawkes, A. (2014). Fulachtaí fia and Bronze Age cooking in Ireland: Reappraising the evidence. Proceedings of the Royal Irish Academy, 115C, 47-77.

Jones, G., \& Legge, A. J. (2008). Evaluating the role of cereal cultivation in the Neolithic: Charred plant remains from Hambledon Hill. In R. Mercer \& F. Healy (Eds.), Hambledon Hill, Dorset, England: Excavation and survey of a Neolithic monument complex and its surrounding landscape (Vol. 2, pp. 469-476). Swindon: English Heritage Archaeological Reports.

Kelly, R. L., Surovell, T. A., Shuman, B. N., \& Smith, G. M. (2013). A continuous climatic impact on Holocene human population in the Rocky Mountains. Proceedings of the National Academy of Sciences, 110(2), 443-447. doi:10.1073/pnas.1201341110.

Kirby, M. (2011) Lockerbie Academy: Neolithic and Early Historic timber halls, a Bronze Age cemetery, an undated enclosure and a post-medieval corn-drying kiln in south-west Scotland, Scottish Archaeological Internet Reports 46. Edinburgh: Society of Antiquaries of Scotland.

Kerr, T., \& McCormick, F. (2013). Statistics sunspots and settlement: Influences on sum of probability curves. Journal of Archaeological Science, 41, 493-501. doi:10.1016/j.jas.2013.09.002.

Kytmannow, T. (2008). Portal tombs in the landscape: The chronology, morphology and landscape setting of the portal tombs of Ireland, Wales and Cornwall, British Archaeological Reports (British Series) 455. Oxford: Archaeopress.

Lanting, J. N., \& Brindley, A. L. (1998). Dating cremated bone: The dawn of a new era. Journal of Irish Archaeology, 9, 1-7.

Lynch, A. (Ed.). (2014). Poulnabrone: An Early Neolithic portal tomb in Ireland, Archaeological Monograph Series no. 9. Dublin: Department of Arts, Heritage and the Gaeltacht.

MacLeod, I. M., Larkin, D. M., Lewin, H. A., Hayes, B. J., \& Goddard, M. E. (2013). Inferring demography from runs of homozygosity in whole-genome sequence, with correction for sequence errors. Molecular Biology and Evolution, 30(9), 2209-2223.

Mallory, J. P., Nelis, E., \& Hartwell, B. (2011). Excavations at Donegore Hill, Co. Antrim. Bray: Wordwell.

McClatchie, M., Bogaard, A., Colledge, S., Whitehouse, N. J., Schulting, R. J., Barratt, P., \& McLaughlin, T. R. (2014). Neolithic farming in northwestern Europe: Archaeobotanical evidence from Ireland. Journal of Archaeological Science, 51, 206-215.

McSparron, C. (2003). The excavation of a Neolithic house in Enagh townland, Co. Derry. In I. Armit, E. Murphy, E. Nelis, \& D. Simpson (Eds.), Neolithic settlement in Ireland and western Britain (pp. 172-175). Oxford: Oxbow.

McSparron, C. (2008). Have you no homes to go to? Archaeology Ireland, 22, 18-21. 
Mitchell, F. J. G. (2005). How open were European primaeval forests? Hypothesis testing using palaeoecological data. Journal of Ecology, 93, 168-177.

Montgomery, W. I., Provan, J., McCabe, A. M., \& Yalden, D. W. (2014). Origin of British and Irish mammals: Disparate post-glacial colonisation and species introductions. Quaternary Science Reviews, 98, 144-165.

Müller, J., Seregély, T., Becker, C., Christensen, A.-M., Fuchs, M., Kroll, H., et al. (2009). A revision of Corded Ware settlement pattern: New results from the Central European low mountain range. Proceedings of the Prehistoric Society, 75, 125-142.

Murphy, E., Ó Donnabháin, B., Welsh, H., \& McGranaghan, C. (2010). INSTAR: The people of prehistoric Ireland. Phase 1. Archaeology Ireland, 24(1), 23-25.

Murray, H., Murray, C., \& Fraser, S. (Eds.). (2009). A tale of the unknown unknowns: A Mesolithic pit alignment and a Neolithic timber hall at Warren Field, Crathes, Aberdeenshire. Oxford: Oxbow.

Ó Néill, J. (2009). Burnt mounds in northern and western Europe: A study of prehistoric technology and society. Saarbrüken: Verlag Dr. Müller.

O'Brien, W. (2012). The Chalcolithic in Ireland: A chronological and cultural framework. In M. J. Allen, J. Gardiner, A. Sheridan, \& D. McOmish (Eds.), The British Chalcolithic: Place and polity in the later 3rd millennium BC (pp. 211-225). Oxford: Oxbow.

O'Connell, A. (2003). Fermoy 2, Co Cork, 03E0979. Unpublished excavation report. Archaeological Consultancy Services Limited.

O'Connell, T. (2009). N9/N10 Kilcullen to Waterford Scheme: Kilcullen to Powerstown. Archaeological Services Contract No. 4-Resolution, Prumplestown to Powerstown. Final Report on archaeological investigations at Site E2589, in the townland of Tinryland, Co. Carlow. Unpublished excavation report: Headland Archaeology Ltd.

O'Connell, M., \& Molloy, K. (2001). Farming and woodland dynamics in Ireland during the Neolithic. Biology and Environment (Proceedings of the Royal Irish Academy Series B), 101, 99-128.

O'Kelly, M. J. (1982). Newgrange: Archaeology, art and legend. London: Thames \& Hudson.

O'Kelly, M. J. (1989). Early Ireland: An introduction to Irish Prehistory. Cambridge: Cambridge University Press.

O’Sullivan, A., McCormick, F., Kerr, T. R., \& Harney, L. (2014). Early medieval Ireland AD 400-1100: The evidence from archaeological excavations. Dublin: Royal Irish Academy.

Pelling, R., \& Campbell, C. (2013). The plant resources. In M. Canti, C. Campbell \& S. Greaney (Eds), Stonehenge World Heritage Site synthesis: Prehistoric landscape, environment and economy. English Heritage Research Department Report Series 45 (pp. 37-60). Portsmouth: English Heritage.

Peros, M., Munoz, S., Gajewski, K., \& Viau, A. (2010). Prehistoric demography of North America inferred from radiocarbon data. Journal of Archaeological Science, 37, 656-664. doi:10.1016/j.jas.2009.10. 029.

Pilcher, J. R. (1969). Archaeology, palaeoecology and ${ }^{14} \mathrm{C}$ dating of the Beaghmore stone circle site. Ulster Journal of Archaeology, 32, 73-91.

Reimer, P. J., Bard, E., Bayliss, A., Beck, J. W., Blackwell, P. G., Bronk Ramsey, C., et al. (2013). IntCal13 and Marine13 radiocarbon age calibration curves 0-50,000 years cal BP. Radiocarbon, 55(4), 1869-1887.

Roland, T., Daley, T., Caseldine, C., Charman, D., Turney, C., Amesbury, M., et al. (2015). The 5.2 ka climate event: Evidence from stable isotope and multi-proxy palaeoecological peatland records in Ireland. Quaternary Science Reviews, 124, 209-223.

Rowley-Conwy, P. (2004). How the West was lost: A reconsideration of agricultural origins in Britain, Ireland, and southern Scandinavia. Current Anthropology, 45(supplement), S83-S113.

Schiffer, M. B. (1987). Formation processes of the archaeological record. Albuquerque: University of New Mexico Press.

Schulting, R. J. (2011). The radiocarbon dates from Tullahedy. In R. M. Cleary \& H. Kelleher (Eds.), Excavations at Tullahedy, Co. Tipperary: Neolithic settlement in North Munster (pp. 145-161). Cork: Collins Press.

Schulting, R. J. (2014). The dating of Poulnabrone, Co. Clare. In A. Lynch (Ed.), Poulnabrone, Co. Clare: Excavation of an Early Neolithic portal tomb, Archaeological Monograph Series (pp. 93-113). Dublin: Department of Arts, Heritage and the Gaeltacht.

Schulting, R. J. (2015). Dating the construction of Newgrange. In A. Lynch, Newgrange revisited: New insights from excavations at the back of the mound 1984-1985. Journal of Irish Archaeology, 23, 46-50.

Schulting, R. J., Bronk Ramsey, C., Reimer, P. J., Eogan, G., Cleary, K., Cooney, G., et al. (2016). Dating the human remains from Knowth. In G. Eogan \& K. Cleary (Eds.), Excavations at Knowth 6: The 
archaeology of the large passage tomb at Knowth, Co. Meath. Dublin: Royal Irish Academy. (forthcoming).

Schulting, R. J., Murphy, E., Jones, C., \& Warren, G. (2012). New dates from the north and a proposed chronology for Irish court tombs. Proceedings of the Royal Irish Academy, 112C, 1-60.

Schulting, R. J., \& Reimer, P. J. (2008). Appendix 7: AMS ${ }^{14} \mathrm{C}$ dating of cereal remains (in R. M. Chapple, The excavation of Early Neolithic and Early Bronze Age sites at Oakgrove, Gransha, County Londonderry). Ulster Journal of Archaeology, 67, 53-55.

Schulting, R. J., Sheridan, A., Clarke, S., \& Bronk Ramsey, C. (2008). Largantea and the dating of Irish wedge tombs. Journal of Irish Archaeology, 17, 1-17.

Shennan, S. (2013). Demographic continuities and discontinuities in Neolithic Europe: Evidence, methods and implications. Journal of Archaeological Method and Theory, 20, 300-311.

Shennan, S., Downey, S. S., Timpson, A., Edinborough, K., Colledge, S., Kerig, T., et al. (2013). Regional population collapse followed initial agriculture booms in mid-Holocene Europe. Nature Communications, 4, 2486. doi:10.1038/ncomms3486.

Shennan, S., \& Edinborough, K. (2006). Prehistoric population history: From the Late Glacial to the Late Neolithic in central and northern Europe. Journal of Archaeological Science, 34, 1139-1145.

Sheridan, J. A. (2004). Neolithic connections along and across the Irish Sea. In V. Cummings \& C. Fowler (Eds.), The Neolithic of the Irish Sea: Materiality and traditions of practice (pp. 9-21). Oxford: Oxbow.

Sheridan, J. A. (2010). The Neolithization of Britain and Ireland: The 'big picture'. In B. Finlayson \& G. Warren (Eds.), Landscapes in transition (pp. 89-105). Oxford: Oxbow.

Sheridan, J. A., \& Pétrequin, P. (2014). Constructing a narrative for the Neolithic of Britain and Ireland: The use of 'hard science' and archaeological reasoning. In A. Whittle \& P. Bickle (Eds.), Early farmers: The view from archaeology and science, Proceedings of the British Academy 198 (pp. 369-390). Oxford: Oxford University Press/The British Academy.

Smyth, J. (2006). The role of the house in Early Neolithic Ireland. European Journal of Archaeology, 9, $229-257$.

Smyth, J. (2007). Neolithic settlement in Ireland: New theories and approaches. Unpublished Ph.D. dissertation, University College Dublin, Dublin.

Smyth, J. (2010). The house and group identity in the Irish Neolithic. Proceedings of the Royal Irish Academy, C111, 1-31.

Smyth, J. (2012). Breaking ground: An overview of pits and pit-digging in Neolithic Ireland. In $H$. Anderson-Whymark \& J. Thomas (Eds.), Regional perspectives on Neolithic pit deposition: Beyond the mundane (pp. 13-29). Oxford: Oxbow.

Smyth, J. (2014). Settlement in the Irish Neolithic: New discoveries at the edge of Europe. Prehistoric Society Research Paper 6. Oxford: Oxbow.

Smyth, J., \& Evershed, R. P. (2015). The molecules of meals: New insight into Neolithic foodways. Proceedings of the Royal Irish Academy, 115C, 27-46. doi:10.3318/priac.2015.115.07.

Snoeck, C., Brock, F., \& Schulting, R. J. (2014). Carbon exchanges between bone apatite and fuels during cremation: Impact on radiocarbon dates. Radiocarbon, 56(2), 591-602.

Steig, E. J. (1999). Mid-Holocene climate change. Science, 286, 1485-1487.

Stevens, C. J., \& Fuller, D. Q. (2012). Did Neolithic farming fail? The case for a Bronze Age agricultural revolution in British Isles. Antiquity, 86, 707-722.

Stout, M. (1996). Emyr Estyn Evans and Northern Ireland: The archaeology and geography of a new state. In J. A. Atkinson, I. Banks, \& J. O’Sullivan (Eds.), Nationalism and archaeology (pp. 111-127). Glasgow: Cruithne Press.

Stuijts, I., O’Donnell, L., Corns, L. A., McAuley, J., Shaw, R., Bunce, A., \& O’Sullivan, K. (2010). WODAN: A database for wood and charcoal identifications. Archaeology Ireland, 24(4), 40-42.

Surovell, T. A., Finley, J. B., Smith, G. M., Brantingham, P. J., \& Kelly, R. (2009). Correcting temporal frequency distributions for taphonomic bias. Journal of Archaeological Science, 36, 1715-1724.

Taylor, K. (2006). N18 Ennis Bypass and N85 Western Relief Road, Site AR127, Cahircalla More, Co. Clare: A final archaeological excavation report for Clare County Council Licence No: 04E0028. Unpublished excavation report. Technical report, TVAS Ireland.

Thomas, J. (2004). Current debates on the Mesolithic-Neolithic transition in Britain and Ireland. Documenta Praehistorica, 31, 113-130.

Timpson, A., Colledge, S., Crema, E., Edinborough, K., Kerig, T., Manning, K., et al. (2014). Reconstructing regional population fluctuations in the European Neolithic using radiocarbon dates: A new case-study using an improved method. Journal of Archaeological Science, 52, 549-557.

Waddell, J. (1970). Irish Bronze Age cists: A survey. Journal of the Royal Society of Antiquaries of Ireland, 100, 91-139. 
Waddell, J. (1990). The Bronze Age burials of Ireland. Galway: Galway University Press.

Warren, G. (2008). Fieldwork in Belderrig, 2004-2008. Unpublished excavation report, University College Dublin.

Warren, G., Davis, S., McClatchie, M., \& Sands, R. (2014). The potential role of humans in structuring the wooded landscapes of Mesolithic Ireland: A review of data and discussion of approaches. Vegetation History and Archaeobotany, 23(5), 629-646. doi:10.1007/s00334-013-0417-z.

Warren, G., Little, A., \& Stanley, M. (2009). A late Mesolithic lithic scatter and radiocarbon dates from Corralanna, Co., Westmeath. Proceedings of the Royal Irish Academy, 109C, 1-35.

Whitehouse, N. J. (2006). The Holocene British and Irish ancient woodland fossil beetle fauna: Implications for forest history, biodiversity and faunal colonisation. Quaternary Science Reviews, 25, 1755-1789.

Whitehouse, N. J., Schulting, R. J., McClatchie, M., Barratt, P., McLaughlin, T. R., Bogaard, A., et al. (2014). Neolithic agriculture on the European western frontier: The boom and bust of early farming in Ireland. Journal of Archaeological Science, 51, 181-205.

Whittle, A. (1996). Neolithic Europe: A survey (2nd ed.). Cambridge: Cambridge University Press.

Whittle, A., Healy, F., \& Bayliss, A. (Eds.). (2011). Gathering time: Dating the Early Neolithic enclosures of southern Britain and Ireland. Oxford: Oxbow.

Wicks, K., \& Mithen, S. (2014). The impact of the abrupt 8.2 ka cold event on the Mesolithic population of western Scotland: A Bayesian chronological analysis using 'activity events' as a population proxy. Journal of Archaeological Science, 45, 240-269.

Wicks, K., Pirie, A., \& Mithen, S. J. (2014). Settlement patterns in the late Mesolithic of western Scotland: The implications of Bayesian analysis of radiocarbon dates and inter-site technological comparisons. Journal of Archaeological Science, 41, 406-422.

Williams, A. N. (2012). The use of summed radiocarbon probability distributions in archaeology: A review of methods. Journal of Archaeological Science, 39, 578-589.

Woodbridge, J., Fyfe, R. M., Roberts, N., Downey, S., Edinborough, K., \& Shennan, S. (2014). The impact of the Neolithic agricultural transition in Britain: A comparison of pollen-based land-cover and archaeological ${ }^{14} \mathrm{C}$ date-inferred population change. Journal of Archaeological Science, 51, 216-224.

Woodman, P. C. (1985). Prehistoric settlement and environment. In K. J. Edwards \& W. Warren (Eds.), The Quaternary history of Ireland (pp. 251-278). London: Academic Press.

Woodman, P. C. (1992). Filling in the spaces in Irish prehistory. Antiquity, 66, 295-314.

Woodman, P. C. (2000). Hammers and shoeboxes: New agendas for Irish Prehistory. In A. Desmond, G. Johnson, M. McCarthy, J. Sheehan, \& E. Shee Twohig (Eds.), New agendas in Irish Prehistory: Papers in commemoration of Liz Anderson (pp. 1-14). Bray: Wordwell.

Woodman, P. C. (2015). Ireland's first settlers: Time and the Mesolithic. Oxford: Oxbow.

Woodman, P. C., Anderson, E., \& Finlay, N. (1999). Excavations at Ferriter's Cove, 1983-1995: Last foragers, first farmers in the Dingle Peninsula. Bray: Wordwell.

Woodman, P. C., McCarthy, M., \& Monaghan, N. (1997). The Irish Quaternary Faunas Project. Quaternary Science Reviews, 16, 129-159. 